\title{
Curiosity in old age: a possible key to achieving adaptive aging
}

Article

Accepted Version

Creative Commons: Attribution-Noncommercial-No Derivative Works 4.0

Sakaki, M., Yagi, A. and Murayama, K. (2018) Curiosity in old age: a possible key to achieving adaptive aging. Neuroscience and Biobehavioral Reviews, 88. pp. 106-116. ISSN 0149-7634 doi: https://doi.org/10.1016/j.neubiorev.2018.03.007 Available at https://centaur.reading.ac.uk/75889/

It is advisable to refer to the publisher's version if you intend to cite from the work. See Guidance on citing.

To link to this article DOI: http://dx.doi.org/10.1016/j.neubiorev.2018.03.007

Publisher: Elsevier

All outputs in CentAUR are protected by Intellectual Property Rights law, including copyright law. Copyright and IPR is retained by the creators or other copyright holders. Terms and conditions for use of this material are defined in the End User Agreement.

\section{www.reading.ac.uk/centaur}

\section{CentAUR}

Central Archive at the University of Reading

Reading's research outputs online 
Curiosity in old age: A possible key to achieving adaptive aging

$$
\text { Michiko Sakaki }{ }^{1,2} \text {, Ayano Yagi², \& Kou Murayama }{ }^{1,2}
$$

${ }^{1}$ School of Psychology and Clinical Language Sciences, University of Reading, Harry

Pitt Building, Earley Gate, Whitenights road, Reading, UK, RG6 7BE

${ }^{2}$ Kochi Technology of University, 185, Tosayamada, Miyanokuchi, Kami City, Kochi, 782-8502, JAPAN

Corresponding author:

Michiko Sakaki

Email: $\underline{\text { m.sakaki@reading.ac.uk }}$

Address: School of Psychology and Clinical Language Sciences

University of Reading

Harry Pitt Building

Earley Gate, Whitenights road, Reading, UK, RG6 7BE

Conflicts of interest: none

Keywords: curiosity, aging, cognitive preservation, locus coeruleus, openness to experience 
Life was meant to be lived, and curiosity must be kept alive. One must never, for whatever reason, turn his back on life.

- Eleanor Roosevelt (1961)

Curiosity is a fundamental motivation in humans. Although the literature still lacks a widely accepted definition of curiosity and there have been several variations in its definition (Berlyne, 1954; Collins, Litman, \& Spielberger, 2004; Kidd \& Hayden, 2015; Litman, 2008; Loewenstein, 1994; Oudeyer, Gottlieb, \& Lopes, 2016; Silvia, 2005, 2008), most researchers agree that curiosity represents a motivation or desire to seek and learn new information by exploring novel or uncertain environments (Kashdan \& Silvia, 2009). Especially visible in early childhood, curiosity has received attention in the literature of child development (Engel, 2011; Smock \& Holt, 1962) and education (Grossnickle, 2016; Klahr, Zimmerman, \& Jirout, 2011; Oudeyer et al., 2016). These studies have found that curiosity plays a central role in children's learning, predicting academic achievement and achievement motivation (Renninger \& Hidi, 2016; Von Stumm, Hell, \& Chamorro-Premuzic, 2011). Curiosity also plays critical roles beyond the context of child development and education, supporting a variety of activities like consumer behaviors (Steenkamp \& Baumgartner, 1992), job performance (Mussel, 2013), and scientific discoveries (Simon, 2001).

In the current paper, we provide a literature overview of one of the most underappreciated topics on curiosity—curiosity in old age. We argue that, although curiosity generally declines with age, it plays an important role in maintaining cognitive function, mental health, and physical health in older adults. In contrast to the literature in 
child development and education, the existing literature on curiosity in older adults is rather sparse and the few relevant topics are largely isolated from each other. Furthermore, whereas some studies examine curiosity by focusing on a phasic emotional and motivational state evoked when faced with novel and interesting stimuli, other studies measure individual differences in trait curiosity (individual differences in a tendency to experience curiousity; Litman \& Spielberger, 2003) using self-reported questions, with little attempt to compare or reconcile findings across the different methodologies. In addition, studies on similar concepts (e.g., novelty seeking, experience seeking and sensation seeking) provide useful insights into curiosity, but this link tends to be overlooked in the existing literature. Our aim in the current paper is to join these different lines of research and assert the importance of curiosity in the aging population.

\section{Effects of Age on Curiosity}

Previous studies on subjective feelings of curiosity and aging suggest that normal aging leads to a decline in at least some aspects of curiosity. For example, in a crosssectional survey study on a nationally representative sample in the UK, Robinson, Demetre, and Litman (2017) showed a decline from early to late adulthood in three distinct dimensions of curiosity: interpersonal curiosity, a desire to find out information about other people, such as feelings of other people and what other people do; epistemic curiosity, an intellectual desire for new knowledge; and intrapersonal curiosity, a desire to find out new information about the self (see also Renner, 2006).

This age-related decline in curiosity is consistent with findings from studies of personality traits that are related to individual differences in trait curiosity. One example 
is openness to experience from the Big Five personality traits (Kashdan et al., 2009; Kashdan, Rose, \& Fincham, 2004), which refers to individuals' willingness to explore, tolerate, and consider new and unfamiliar ideas and experiences (McCrae \& Costa, 1987). Previous research has shown that, although scores for some personality traits increase with age (e.g., agreeableness; conscientiousness), openness to experience decreases with age (Costa, Herbst, McCrae, \& Siegler, 2000; McCrae et al., 1999; McCrae et al., 2000; Ziegler, Cengia, Mussel, \& Gerstorf, 2015). Another trait which is related to curiosity is sensation seeking. Sensation seeking represents individual differences in the 'optimal level of stimulation' and refers to one's tendency to seek varied, novel, complex, and intense sensations and experiences (Zuckerman, Buchsbaum, \& Murphy, 1980). Like openness to experience, sensation seeking appears to decrease with age (Lawton, Kleban, Rajagopal, \& Dean, 1992; Zuckerman, Eysenck, \& Eysenck, 1978). Closely related to sensation seeking, age-related declines in subjective feelings of stimulation seeking (i.e., a tendency to take part in stimulating activities) have also been confirmed via longitudinal study (Giambra, Camp, \& Grodsky, 1992). Research on apathy-a lack of motivation and interest, including indifference towards having new experiences_-further reveals that normal aging is associated with increased apathy (Brodaty, Altendorf, Withall, \& Sachdev, 2010), consistent with agerelated declines in curiosity.

Age-related reductions in exploratory behaviors in novel situations are also evident in animal research (e.g., Mroczek \& Kolarz, 1998; Van Waas \& Soffié, 1996). In one study, for example, young and old rats were habituated to two bottles with water for five days; on the sixth day, water in one of the bottles was replaced by a saccharin 
solution (Collier, Greene, Felten, Stevens, \& Collier, 2004). While young rats preferred the saccharin solution over the water in the other bottle despite its novelty, old rats showed reduced preference for the novel saccharin solution over the water bottle (see also Dellu, Mayo, Valleé, Le Moal, \& Simon, 1994). In summary, previous research suggests that normal aging is associated with reduced curiosity and reduced exploration behaviors in novel environments.

\section{Brain Mechanisms underlying Curiosity in Old Age}

What are the brain mechanisms underlying these age-related changes? To address this question, we will first provide a brief review of the brain mechanisms underlying curiosity and then explain how normal aging affects these brain regions.

\subsection{Brain mechanisms of curiosity}

While research on the neural mechanisms underlying subjective feelings of curiosity is still sparse, substantial research has addressed the neural mechanisms underlying exploration driven by novelty and uncertainty (for a review see Schomaker \& Meeter, 2015). Novelty is defined as per the number of times that the stimulus has been previously encountered, while uncertainty is defined as per the unreliability of consequent outcomes (Gottlieb, Oudeyer, Lopes, \& Baranes, 2013; Yu \& Dayan, 2005). Thus, these two concepts are related but can be independently operationalized (e.g., one can feel uncertain about an outcome irrespective of whether the outcome is familiar or novel). Nevertheless, previous studies show some overlap in the brain regions involved in these processes and indicate the possibility that brain regions implicated in rewards and emotion play important roles in curiosity.

The first set of regions implicated in curiosity is the mesolimbic dopaminergic 
system (Figure 1A). Exposure to novel stimuli induces activation of subcortical rewardrelated regions, including the nucleus accumbens (NAc), substantia nigra (SN), and ventral tegmental area (VTA; Axmacher et al., 2010; Bunzeck \& Düzel, 2006; Bunzeck, Guitart-Masip, Dolan, \& Duzel, 2014; Krebs, Heipertz, Schuetze, \& Duzel, 2011; Wittmann, Bunzeck, Dolan, \& Düzel, 2007; Wittmann, Daw, Seymour, \& Dolan, 2008). Individuals with high novelty-seeking tendencies also show greater activity in these regions than those with low novelty-seeking tendencies when exposed to novel stimuli (Krebs, Schott, \& Düzel, 2009). Animal research provides further support for the role of the dopaminergic system in curiosity (Bardo, Donohew, \& Harrington, 1996): when animals are exposed to a novel environment, they show increased dopaminergic signals in the NAc (Legault \& Wise, 2001; Piazza et al., 1991; Rebec, Christensen, Guerra, \& Bardo, 1997; Rebec, Grabner, Johnson, Pierce, \& Bardo, 1996) and increased firing rates of dopaminergic neurons in the SN (Ljungberg, Apicella, \& Schultz, 1992).

Recent neuroimaging studies have examined the neural mechanisms underlying curiosity more directly by employing tasks that induce subjective feelings of curiosity. These studies also indicate the importance of the dopaminergic system in curiosity (Kang et al., 2009; for a review see Kidd \& Hayden, 2015). For example, Gruber and colleagues presented participants with trivia questions that differed in curiosity levels and found that trivia questions with higher curiosity was associated with stronger activity in the striatum and SN/VTA (Gruber, Gelman, \& Ranganath, 2014). The striatum has been also implicated in the relief of perceptual curiosity (i.e., when curiosity triggered by the presentation of ambiguous visual input was satisfied by disambiguation; Jepma, Verdonschot, van Steenbergen, Rombouts, \& Nieuwenhuis, 2012). 
The studies described so far have focused on the dopaminergic reward-related areas, but accumulating evidence suggests that processing of novel and uncertain stimuli is also associated with the noradrenergic system (Figure 1B), in particular the locus coeruleus (LC), a primary source of norepinephrine in the brain (e.g., Devauges \& Sara, 1990; Gompf et al., 2010). Indeed, pupil dilation, a peripheral measure of LC activity (Joshi, Li, Kalwani, \& Gold, 2016; Murphy, O'Connell, O'Sullivan, Robertson, \& Balsters, 2014), tracks unpredictability during tasks (Lavin, San Martín, \& Rosales Jubal, 2014). A recent neuroimaging study suggests that the LC is involved in processing uncertainty in humans (Payzan-LeNestour, Dunne, Bossaerts, \& O'Doherty, 2013). In addition, changes in pupil dilation owing to uncertainty have been associated with better learning rates (Nassar et al., 2012). Likewise, phasic arousal induced by something emotional (which is associated with the LC activity) modulates learning and hippocampal functioning (Mather, Clewett, Sakaki, \& Harley, 2016; Sakaki, Fryer, \& Mather, 2014). Thus, the LC may also be related to curiosity-enhanced learning.

Animal studies further support the role of the LC in processing novelty and uncertainty (Delini-Stula, Mogilnicka, Hunn, \& Dooley, 1984; Harro, Oreland, Vasar, \& Bradwejn, 1995). In one study, rats were habituated to a box which included nine holes symmetrically cut in the floor (Devauges \& Sara, 1990). After habituation, objects were added in four holes and the rats were given idazoxan (an alpha2 adrenergic antagonist) or a control treatment. Idazoxan increased the time that rats spent exploring the holes with novel and unexpected objects, particularly those with complex objects, but did not affect exploration of the empty holes. Subsequent research confirms that administration of alpha2 adrenergic receptor agonists and beta receptor antagonists eliminate this 
preference towards holes with novel objects (Sara, Dyon-Laurent, \& Hervé, 1995; see also Vankov, Hervé-Minvielle, \& Sara, 1995).

\section{2. Effects of age on brain regions important for curiosity}

As reviewed in the previous section, the dopaminergic system and the noradrenergic system underlie exploration behaviors based on novelty and uncertainty in young adults and animals. Previous research also suggests that similar brain regions play critical roles in curiosity in older adults. For example, exposure to novel stimuli evoked activation in the SN/VTA in older adults like that seen in younger adults (Bunzeck \& Düzel, 2006; Bunzeck et al., 2007). Norepinephrine release in the cingulate cortex - a region which has strong projections from the LC (B. E. Jones \& Moore, 1977) — was also associated with intact exploratory behaviors in novel environments in old rats (Collier, Greene, Felten, Stevens, \& Collier, 2004).

The dopaminergic system and the noradrenergic system are also susceptible to age-related decline. Past research has documented age-related declines in the striatum structure (Raz et al., 2003; Walhovd et al., 2005), striatal dopamine levels (Collier et al., 2007; Haycock et al., 2003), the number of dopaminergic D1 and D2 receptors in the striatum (Rinne et al., 1993; Rinne, Lönnberg, \& Marjamäki, 1990), responsivity of the striatum to reward learning (Chowdhury et al., 2013; Eppinger, Schuck, Nystrom, \& Cohen, 2013; Schott et al., 2007), and D2 receptor binding in the striatum (Bäckman et

al., 2000; for reviews see Bäckman, Lindenberger, Li, \& Nyberg, 2010; Düzel, Bunzeck, Guitart-Masip, \& Düzel, 2010; Kaasinen \& Rinne, 2002; Reeves, Bench, \& Howard, 2002). Previous research has also shown increased iron accumulation in the striatum with age (Steiger, Weiskopf, \& Bunzeck, 2016), as well as high exposure of SN neurons 
to iron (Zecca, Stroppolo, et al., 2004). Given that iron exposure leads to oxidative stress and neuronal loss (Zecca, Youdim, Riederer, Connor, \& Crichton, 2004), these results further suggest that the dopaminergic neurons are particularly vulnerable to oxidative stress during aging. Furthermore, animal research reveals reduced dopamine concentration levels in the striatum (Míguez, Aldegunde, Paz-Valiñas, Recio, \& Sánchez-Barceló, 1999) and neuronal loss in the SN (Emborg et al., 1998) in aged brains. The age-related change in the dopaminergic function was not limited to the striatum and the SN (Bach et al., 1999; Míguez et al., 1999). For example, studies have shown the reduced density of D2 receptors in the hippocampus (Amenta et al., 2001) and reduced mRNA levels for D1-D5 receptors in the CA1 neurons in the hippocampus with age (Hemby, Trojanowski, \& Ginsberg, 2003).

The noradrenergic system also shows decline with age. The density of alpha2 receptors declines in aging in monkeys (Bigham \& Lidow, 1995). Likewise, alpha1 and alpha2 noradrenergic receptor bindings in the prefrontal cortex (PFC) were lower in older monkeys than in younger monkeys (Moore et al., 2005). Aging was also associated with reduced firing rates of LC neurons (Olpe \& Steinmann, 1982), reduced density of beta adrenergic receptors (Greenberg \& Weiss, 1978), the impaired synthesis of alpha1 and alpha2 receptors (Zhou, Weiss, Freilich, \& Greenberg, 1984), and altered sensitivity of neurons to norepinephrine in rodents (R. S. G. Jones \& Olpe, 1984; R. S. G. Jones \& Olpe, 1983). The density of norepinephrine transporter (NET) in LC also declines with age in humans (Ding et al., 2010). Since NET plays critical roles in NE signaling (Jayanthi \& Ramamoorthy, 2005), these results further suggest that normal aging is associated with changes in the action of norepinephrine in the brain. 
Furthermore, exposure to novel stimuli often induces the P3 component of the event related potential (ERP), but normal aging is associated with a decline in the amplitude of the P3 component (Czigler, Pató, Poszet, \& Balázs, 2006; Fabiani \& Friedman, 1995; Friedman, Kazmerski, \& Cycowicz, 1998). Though the exact neural mechanisms underlying the P3 component are not yet known, the LC is a candidate region (Murphy, Robertson, Balsters, \& O'Connell, 2011; Nieuwenhuis, Aston-Jones, \& Cohen, 2005). Thus, the age-related decline in P3 amplitude suggests that aging is linked to impaired LC function. The impaired function and structure of the brain regions critical for curiosity in older adults may in turn lead to the aforementioned reductions in subjective feelings of curiosity.

\section{Motivational Factors that Affect Curiosity in Old Age}

Aging is associated not only with changes in neural structure and function, but also with changes in one's motivation. According to the socioemotional selectivity theory (SST) (Carstensen, 1995; Carstensen, Isaacowitz, \& Charles, 1999; Carstensen \& TurkCharles, 1994), people have two broad goal categories: a) to acquire knowledge, seek novelty, and expand breadth of knowledge and b) to regulate negative, and maintain positive, emotional states. These goals operate across the lifespan, such that people are generally motivated to learn new knowledge and maintain positive emotional states.

SST further posits that when individuals are young or perceive their future time as more open-ended, they are more likely to focus on information-seeking goals over emotion-regulation goals in preparation for the uncertain future. In contrast, people are more likely to favor emotion-regulation goals and optimizing their psychological wellbeing when they perceive time as being limited. Consistent with the predictions of 
SST, older adults, relative to younger adults, tend to prefer interactions with familiar people over new people (Fredrickson \& Carstensen, 1990), have a smaller size of social networks than do younger adults (Fung, Carstensen, \& Lang, 2001; Lang \& Carstensen, 1994; Lang \& Carstensen, 2002; Wrzus, Hanel, Wagner, \& Neyer, 2013), and show reduced exploration behaviors in their social life. Older adults also tend to remember and pay attention to more positive information than negative information (Löckenhoff \& Carstensen, 2004; Löckenhoff \& Carstensen, 2007; Mikels et al., 2010). These agerelated differences can be weakened when motivations are manipulated to elicit the information-gathering goal or time perspectives are manipulated to think of time as being expansive (Barber, Opitz, Martins, Sakaki, \& Mather, 2016; Kellough \& Knight, 2012; Löckenhoff \& Carstensen, 2007). These results suggest that at least some of the effects of age on curiosity are driven by motivational shifts with age, rather than structural or functional changes in the brain.

\section{Curiosity as a Proxy for Adaptive Aging}

As reviewed so far, previous studies with respect to personality psychology, animal behavior, neuroimaging, and social psychology are consistent with the notion that curiosity declines with advanced age. However, accumulating evidence also suggests that curiosity may actually play a critical role in maintaining cognitive functioning, wellbeing and physical health in older adults.

In this section, we argue that momentary feelings of curiosity can help older adults' mental functions, because phasic activation of the noradrenergic and dopaminergic systems modulate brain functioning, facilitating our mental processing which often declines with age (Figure 2). In addition to the short-term effects of 
curiosity, we also point out that a chronic tendency to experience curiosity can have benefits over the course of aging (Figure 3). Below we first provide an explanation about possible mechanisms by which curiosity can have life-long effects, followed by discussions of each domain curiosity appears to help: memory, general cognition, wellbeing, and physical health.

\subsection{Mechanisms underlying the cumulative effects of curiosity}

When one has a general tendency to experience curiosity, such experiences can have cumulative effects and long-term consequences via several mechanisms. First, trait curiosity can affect one's behaviors and facilitate behaviors that are beneficial for adaptive aging. For example, cognitively stimulating activities protect against agerelated declines in cognitive functioning, such as reasoning and episodic memory (Corbett et al., 2016; Ferreira, Owen, Mohan, Corbett, \& Ballard, 2015; Robertson, 2013). Curiosity is often the primary predictor for older adults' engagement in such activities in the first place (Romaniuk \& Romaniuk, 1982). Therefore, those with lower curiosity may engage in fewer stimulating activities and learning opportunities as they age, thus leading to poorer cognitive performance.

Second, accumulating evidence suggests that both norepinephrine and dopamine have neuroprotective effects. Norepinephrine is known to reduce inflammatory responses (for reviews see Braun, Madrigal, \& Feinstein, 2014; Feinstein et al., 2002; Mather \& Harley, 2016; O'Donnell, Zeppenfeld, McConnell, Pena, \& Nedergaard, 2012). For example, norepinephrine depletion facilitates inflammatory reactions and inhibits clearance of beta-amyloid (which is toxic to neurons) in the hippocampus and frontal cortex (Heneka et al., 2010). Likewise, dopamine has an anti- 
inflammatory function (Elgueta et al., 2017; Torres-Rosas et al., 2014; Yan et al., 2014). Increased inflammation has been associated not only with physical pathologies (e.g., infection, stroke) but also with cognitive decline and emotional disorder (e.g., depression; Kuo et al., 2005; McAfoose \& Baune, 2009; Miller, Maletic, \& Raison, 2009). Thus, individuals with a chronic tendency to experience curiosity and seek novel or unexpected events can benefit from the anti-neurodegenerative effects of norepinephrine and dopamine, possibly leading to better cognitive functioning, wellbeing and physical health.

\subsection{Effects of curiosity on memory}

The first type of cognitive processing related to curiosity is memory. The hippocampus receives projections of the dopaminergic (Lisman \& Grace, 2005) and the noradrenergic systems (Figure 1; B. E. Jones \& Moore, 1977). Thus, when individuals encounter something novel/unexpected and experience curiosity, dopamine and norepinephrine can facilitate learning by modulating the hippocampal activity (Oudeyer et al., 2016). Given that the hippocampus is susceptible to age-related declines (Allen, Bruss, Brown, \& Damasio, 2005; Mitchell, Johnson, Raye, \& D'Esposito, 2000; Raz, Ghisletta, Rodrigue, Kennedy, \& Lindenberger, 2010; Walhovd et al., 2005), curiosity may help mitigate impairments to memory functioning due to age. In fact, processing of novel stimuli, relative to familiar stimuli, is associated with increased activity in the hippocampus and enhanced learning in both younger and older adults (Axmacher et al., 2010; Bunzeck, Doeller, Dolan, \& Duzel, 2012; Bunzeck \& Düzel, 2006; Bunzeck et al., 2007; Li, Cullen, Anwyl, \& Rowan, 2003; for a review see Lisman \& Grace, 2005). Younger and older adults also show greater learning when they are uncertain about 
cue-outcome contingencies (Nassar et al., 2016; Nassar et al., 2012). Likewise, younger and older adults remember materials that they find curious better than more boring materials (Fastrich, Kerr, Castel, \& Murayama, in press; McGillivray, Murayama, \& Castel, 2015).

Studies discussed so far focused on memories for materials that evoked curiosity or uncertainty, but the mnemonic effects of curiosity also carry over to other irrelevant materials. In one study, participants explored a novel versus familiar situation in virtual reality followed by a word learning task; exposure to the novel situation facilitated participants' memory for the subsequent words, despite their being irrelevant to the situation itself (Schomaker, van Bronkhorst, \& Meeter, 2014). In another study, trivia questions about which participants were highly curious led to better incidental memory for subsequent (irrelevant) images of faces than did less interesting trivia questions (Gruber, Gelman, \& Ranganath, 2014). In animals, exposure to novel environments facilitates long-term potentiation (LTP), which are mediated by dopaminergic and noradrenergic systems (Li et al., 2003; Li et al., 2013). Exposure to novel environments also facilitates the transition from early LTP to late LTP, which is mediated by noradrenergic (Straube, Korz, Balschun, \& Frey, 2003) and dopaminergic activities (Moncada \& Viola, 2007). Thus, curiosity not only helps individuals remember things they feel curious about but also allow them to remember other temporally proximal information.

In addition to these effects of momentary feelings of curiosity, individuals with a greater tendency to experience curiosity benefit from the protective effects of norepinephrine and dopamine more often throughout their lives (Heneka et al., 2010), 
leading to preserved structural organization in the hippocampus and thereby aiding memory functioning. In fact, a longitudinal study in rodents suggests that greater exploratory behaviors in novel situations during youth predict better memory performance in old age (Dellu et al., 1994). Likewise, in rodents, exposure to novel environments leads to better spatial memory performance (Yang \& Tang, 2011) and a larger volume in the hippocampus (Scholz, Allemang-Grand, Dazai, \& Lerch, 2015). In humans, individual differences in experience seeking — which is related to trait curiosity—correlate with individual differences in hippocampal volume (Martin et al., 2007). Curiosity is thus posited to have lifelong benefits for memory by affecting hippocampal performance and structure.

\subsection{Effects of curiosity on general cognitive performance}

The effects of curiosity on cognition are not limited to memory. Both the dopaminergic and noradrenergic systems project to the PFC (Figure 1) and affect its function, such as top-down regulation, working memory and goal-directed behavior (Arnsten, 2011; Arnsten, Wang, \& Paspalas, 2015; Cools, Sheridan, Jacobs, \& D'Esposito, 2007; Usher, Cohen, Servan-Schreiber, Rajkowski, \& Aston-Jones, 1999). Therefore, when individuals encounter something novel or uncertain, a momentary feeling of curiosity may help their PFC functioning, which typically declines with age (Allen et al., 2005; Nyberg et al., 2010; Raz et al., 2010). In line with this idea, working memory performance is better for novel stimuli than familiar stimuli (Mayer, Kim, \& Park, 2011). Presentation of novel stimuli also facilitates processing of other stimuli that are presented either at the same time or shortly after the novel stimuli (Hoffing \& Seitz, 2015; Wetzel, Widmann, \& Schroger, 2012). Such effects are associated with changes 
in pupil dilation (Hoffing \& Seitz, 2015), suggesting that the noradrenergic system may play roles in the novelty-induced facilitation effects in the PFC functioning (for a review see Schomaker \& Meeter, 2015).

In addition to these documented phasic effects of novelty, studies on individual differences also suggest a link between curiosity and general cognitive functioning. For example, both the noradrenergic (Clewett et al., 2016; Robertson, 2013; Wilson et al., 2013) and dopaminergic systems (MacDonald, Karlsson, Rieckmann, Nyberg, \& Bäckman, 2012; Nagel et al., 2008; Papenberg, Lindenberger, \& Bäckman, 2015) have been associated with cognitive preservation in older adults. In addition, previous research reveals that preference for novel stimuli is associated with better cognitive function in older adults (Daffner et al., 2007; Daffner et al., 2006a, 2006b; Pontifex, Hillman, \& Polich, 2009) and even a reduced risk of Alzheimer's disease (Daffner, Scinto, Weintraub, Guinessey, \& Mesulam, 1992; Fritsch, Smyth, Debanne, Petot, \& Friedland, 2005). In one study, older adults were shown a sequence of stimuli: a standard (a triangle; $70 \%$ of frequency), a target (an inverted triangle; $15 \%$ of frequency), and novel stimuli randomly drawn from a set of unusual line drawings (15\% of frequency; Daffner et al., 2006b). Participants were told to view each picture for however long they wanted and to control the viewing duration by a button press. Across older adults, longer viewing durations of novel stimuli was correlated with better performance on neuropsychological tests, especially those involving attention/executive functions (Daffner et al., 2006b). In the same study, cognitive performance in older adults was associated with P3 ERP amplitudes to novel stimuli, considered a noninvasive measure of LC activity (Murphy et al., 2011; Nieuwenhuis et al., 2005; Pineda, 
Foote, \& Neville, 1989; Pineda \& Westerfield, 1993). Thus, results from this study suggest that higher curiosity levels in old age reflect the preserved noradrenergic system as well as preserved cognitive functioning in older adults.

While these studies do not tell us whether the preserved curiosity or the preserved noradrenergic and dopaminergic system lead to cognitive preservation or the other way around, there is increasing evidence from longitudinal research that curiosity is not only correlated to but also predicts better cognitive functioning. Longitudinal research on openness to experience indicates that individuals with relatively higher openness to experience tend to seek more educational and stimulating opportunities throughout their lives and ultimately exhibit smaller age-related cognitive decline (Chapman et al., 2012; Hogan, Staff, Bunting, Deary, \& Whalley, 2012; Sutin et al., 2011; Williams, Suchy, \& Kraybill, 2013; Ziegler et al., 2015) (but see Sharp, Reynolds, Pedersen, \& Gatz, 2010). Additionally, a recent study of recently retired individuals showed that cognitive performance was predicted by a need for cognition-a tendency to seek and enjoy intellectual activities (Baer et al., 2013). As one's need for cognition is correlated to curiosity (Olson, Camp, \& Fuller, 1984), these results again support the notion that curiosity is protective against age-related cognitive decline. Furthermore, in patients with Mild Cognitive Impairment $(\mathrm{MCl})$, those who experienced apathy were more likely to develop dementia than other $\mathrm{MCl}$ patients later (Lanctôt et al., 2017; Robert et al., 2008; Starkstein, Jorge, Mizrahi, \& Robinson, 2006).

\subsection{Effects of curiosity on mental and physical health}

Brain regions critical for curiosity are important not only for cognitive processing but also for wellbeing. In fact, dopaminergic signals in the striatum are associated with 
various positive affective states (for a review see Burgdorf \& Panksepp, 2006). Given that subjective feelings of curiosity are accompanied by striatum activity (Gruber et al., 2014), it is not surprising that individuals feel positive affective states towards novel or uncertain stimuli (Berlyne, 1970).

In addition to these short-term effects, previous research suggests that the noradrenergic and dopaminergic mechanisms implicated in curiosity have a long-term effect on mental health and wellbeing. For example, recent research shows that LC neuronal loss leads to depression-like behaviors in rodents (Szot et al., 2016). Depression is also associated with smaller P3 ERPs to novel stimuli (Bruder et al., 2009), which, as stated above, has been associated with noradrenergic mechanisms. In fact, depression often co-occurs with apathy (Levy et al., 1998; Marin, Firinciogullari, \& Biedrzycki, 1993) and apathy is often a precursor of depression, such that severe apathy is predictive of subsequent depression (Pedersen, Alves, Aarsland, \& Larsen, 2009; Starkstein et al., 2006). Thus, it appears that levels of curiosity predict not only cognitive performance but also depression.

Past research reports positive correlations between trait curiosity and wellbeing (Park, Peterson, \& Seligman, 2004; Vittersø \& Søholt, 2011). Openness to experience also positively predicts life satisfaction (Vitters $\varnothing, 2003$ ) and is associated with greater resilience (Caska \& Renshaw, 2013; Williams, Rau, Cribbet, \& Gunn, 2009). A diary study on college students further showed that greater curiosity on one day predicted greater life satisfaction on the following day (Kashdan \& Steger, 2007). Animal research also supports the role of curiosity in wellbeing; low novelty-seeking rats exposed to chronic stress for four weeks, for instance, tended to develop anhedonia (i.e., lack of 
reward and pleasure in positive stimuli) more quickly than did high novelty-seeking rats (Stedenfeld et al., 2011). Rats with high novelty-seeking tendencies were also more resilient to maternal separation stress during early life (Clinton, Watson, \& Akil, 2014).

Although the exact mechanisms underlying the effects of curiosity on mental health are unknown, one possibility is that high curiosity leads to greater tendencies to employ flexible and adaptive responses to age-related challenges (Swan \& Carmelli, 1996). Indeed, higher levels of openness to experience have been associated with a greater tendency to gather information about health (Sörensen, Duberstein, Chapman, Lyness, \& Pinquart, 2008), and with enhanced creativity (Feist, 1998). In another study, children's curiosity level was predictive of their tendency to come up with flexible solutions to problems (Greenberger, O'Connor, \& Sorensen, 1971). In addition, high curiosity was predictive of improved efficiency in stopping negative thoughts over time in veterans with suicidal ideation (Denneson, Smolenski, Bush, \& Dobscha, 2017), suggesting that curiosity might help individuals to develop coping skills flexibly.

If curiosity encourages more flexible problem solving, the effects of curiosity should not be limited to mental health and should be observed in other domains. In fact, the effects of curiosity have also been observed in physical function and health (Consedine \& Moskowitz, 2007; Peterson, Park, \& Seligman, 2006). One striking finding in relation to this issue is that higher curiosity predicts a better 5 -year survival rate in older adults even after controlling for a number of other risk factors, such as age, education level, and smoking behaviors (Swan \& Carmelli, 1996). Curiosity also appears to be predictive of physical functioning. For example, apathy (an absence of curiosity) is predictive of daily disabilities such as difficulty in walking, 
dressing/undressing, and taking a bath or shower (Clarke, Ko, Lyketsos, Rebok, \& Eaton, 2010). Higher curiosity was also shown to protect against hypertension and diabetes (Richman et al., 2005). Openness to experience is also predictive of preserved walking abilities (Tolea et al., 2012) and better physical functioning in older adults (Chapman, Duberstein, \& Lyness, 2007; Duberstein et al., 2003), as well as reduced mortality rates (Ferguson \& Bibby, 2012; Jonassaint et al., 2007; Turiano, Avron Spiro, \& Mroczek, 2012).

These results are consistent with the proposed notion that curiosity encourages flexible problem solving and may help people effectively cope with physical and mental problems. Another possible explanation for curiosity's influence on physical health is that the effects of curiosity on mental health mediate the relationship between curiosity and physical health. As described earlier, curiosity appears to reduce negative emotion, enhance positive emotion, and help maintain wellbeing. Critically, negative emotional states are known to be detrimental to physical health (DeSteno, Gross, \& Kubzansky, 2013). For example, higher levels of anxiety and distress predict risk of coronary heart disease approximately 10 years later (Kubzansky, Cole, Kawachi, Vokonas, \& Sparrow, 2006), and individuals with symptoms of posttraumatic stress disorder (PTSD) were more likely to develop coronary heart disease during a 14-year follow-up period than those without PTSD symptoms (Kubzansky, Koenen, Jones, \& Eaton, 2009). Stressinduced activation of the hypothalamus-pituitary-adrenal (HPA) axis also leads to proinflammatory activity, thereby negatively affecting physical health (Eisenberger \& Cole, 2012). In contrast to these negative effects, dopamine (which is released when curiosity is evoked) can attenuate excessive HPA axis activation (Sullivan \& Dufresne, 
2006). Thus, through downregulation of negative emotion and stress, curiosity might help to prevent detrimental effects of negative emotion and stress on physical health.

\subsection{Positive-feedback loop based on curiosity}

In summary, curiosity has diverse positive effects in the course of aging. Momentary feelings of curiosity have positive effects on memory, general cognitive functioning, and wellbeing via engagement of the noradrenergic and dopaminergic systems (Figure 2). In addition, one's chronic tendency to experience curiosity has a life-long impact on memory, general cognitive functioning, wellbeing, and physical health both by changing behaviors and altering the brain function or structure (Figure 3).

We believe this adaptive functioning of curiosity during aging is further supported by a positive feedback loop between curiosity and dopamine/norepinephrine that strengthens the effects of curiosity over time (Figure 4). As reviewed in Section 2, the dopaminergic system and noradrenergic system are critical to support one's curiosity. When one feels curious about uncertain stimuli or an individual has a tendency to experience curiosity and explore novel environments, this will increase his/her exposure to novel or uncertain stimuli-which typically results in increased release of dopamine and norepinephrine in the brain. These neuromodulators in turn have the antiinflammatory and the anti-neurodegenerative effects, helping individuals to maintain their ability to experience curiosity and boost their cognition, wellbeing, and physical health (Figures 2-3), which may further support their exploratory behaviors. This positive feedback loop should play a critical role in sustaining the anti-neurodegenerative mechanisms in the brain and achieving successful and adaptive aging.

\section{Future questions}


In the current paper, we treated curiosity as if it is a unitary concept. However, this concept is more nuanced and multifaceted (Kashdan \& Silvia, 2009). For future research, it would be fruitful to take into account this multifaceted nature of curiosity when examining the role of curiosity in aging. For example, we have argued that aging leads to a decline in curiosity. However, this does not mean that aging leads to decline in all domains of curiosity. Studies often distinguish curiosity for different types of objects or domains (Kidd \& Hayden, 2015; Litman \& Spielberger, 2003)—knowledge (epistemic curiosity), perception (perceptual curiosity), and social issues (interpersonal/social curiosity). In a study by Robinson et al. (2017), whereas the researchers found decline in epistemic and interpersonal curiosity, they did not observe significant effects of age in perceptual curiosity (i.e., individuals' tendency to seek new visual, auditory or tactile experiences; Collins et al., 2004). Thus, there might be some unique characteristics about perceptual curiosity that can result in different age effects. In fact, neuroimaging studies suggest that while feelings of epistemic curiosity are rather rewarding and pleasant (Gruber et al., 2014; Kang et al., 2009), feelings of perceptual curiosity are unpleasant due to lack of something wanted (Jepma et al., 2012). In addition, high curiosity is often accompanied with greater activity of the PFC (Gruber et al., 2014; Kang et al., 2009) but the PFC might be required less for perceptual curiosity than for epistemic curiosity which requires integration of information and existing knowledge. Future research should examine the effects of age on curiosity while considering these different types of curiosity.

Relatedly, the current paper incorporated a range of constructs related to curiosity such as novelty seeking, sensation seeking, apathy and openness to 
experiences. But there is another related but different concept: interest (Grossnickle, 2016; Renninger \& Hidi, 2016). Although researchers have not yet reached consensus on the distinction between curiosity and interest (Grossnickle, 2016), one major view is that, while curiosity represents a motivation or desire to seek and learn new information by exploring novel and uncertain environments, interest (especially what is often called "individual interest", Hidi \& Renninger, 2006) is an enduring affective and psychological state that engages ones to learn information that is linked to the existing knowledge and values of that individual (Hidi \& Renninger, 2006; Izard, 2009). Thus, interest and curiosity certainly overlap, but interest is characterized more by the knowledge and values individual possesses (rather than mere uncertainty reduction or novelty seeking), and is considered to develop over time as the knowledge and values accumulate. Given that people typically acquire more knowledge and elaborated personal values as they age (Salthouse, 2010), interest might not show age-related declines or could even show age-related increase. In fact, previous studies on vocational interests reveal stability of vocational interests across the adult lifespan (Costa, McCrae, \& Holland, 1984; Low, Yoon, Roberts, \& Rounds, 2005). Furthermore, in one study, researchers measured both participants' curiosity (a desire to know the answer to trivia questions) and interest (positive feelings associated with knowledge of the answer) as well as their memory (McGillivray et al., 2015). In this study, while curiosity and interest were positively correlated, their memory performance was more strongly determined by interest than curiosity. Although this study focused on a transient aspect of interest, this result suggests the potential differential role of curiosity and interest in predicting memory performance. Future research should clearly operationalize these different but related 
concepts and address whether they have the same or different mechanisms in affecting our mental processing.

\section{Conclusion}

What helps you to stay healthy and happy as you age? For the past decades, this question has spurred a large number of empirical studies in the literature of aging, but these studies have mainly focused on cognitive, social, or physical factors, such as executive functioning (e.g., Grigsby, Kaye, Baxter, Shetterly, \& Hamman, 1998), social relationships (e.g., Cacioppo, Hawkley, \& Thisted, 2010), and physical exercise (e.g., Colcombe et al., 2004). The current review points to the importance of also considering motivational factors, especially curiosity. While curiosity seems to decline with advancing age, it can also be a proxy for maintaining cognitive functioning, mental health, and physical health in older adults, thus serving as a conduit for "successful aging." Despite the growing interest in curiosity in recent neuroscientific research, empirical research on curiosity and aging remains limited and there are still many unanswered questions concerning the neural mechanisms underlying curiosity and its functional consequences. Continued research addressing these questions about curiosity and aging should improve our understanding of how we can support older adults to age healthily, happily and optimally. 


\section{Acknowledgements}

This research was supported by the Marie Curie Career Integration Grants (PCIG13-GA-2013-618600, CIG630680), JSPS KAKENHI (16H05959, 16KT0002, $16 \mathrm{H} 02053,15 \mathrm{H} 05401$ and 16H06406), a grant from the American Psychological Foundation (F. J. McGuigan Early Career Investigator Prize), Leverhulme Trust Project Grant (RPG-2016-146), and Leverhulme Research Leadership Award (RL-2016-030). We thank Catherine Middlebrooks and Lily FitzGibbon for their helpful comments on earlier versions of the manuscript. 


\section{References}

Allen, J. S., Bruss, J., Brown, C. K., \& Damasio, H. (2005). Normal neuroanatomical variation due to age: The major lobes and a parcellation of the temporal region. Neurobiology of Aging, 26(9), 1245-1260.

doi:10.1016/j.neurobiolaging.2005.05.023

Amenta, F., Mignini, F., Ricci, A., Sabbatini, M., Tomassoni, D., \& Tayebati, S. K. (2001). Age-related changes of dopamine receptors in the rat hippocampus: a light microscope autoradiography study. Mechanisms of Ageing and Development, 122(16), 2071-2083. doi:http://dx.doi.org/10.1016/S0047-

\section{$\underline{6374(01) 00317-7}$}

Arnsten, A. F. T. (2011). Catecholamine influences on dorsolateral prefrontal cortical networks. Biological Psychiatry, 69(12), e89-e99.

doi:10.1016/j.biopsych.2011.01.027

Arnsten, A. F. T., Wang, M., \& Paspalas, C. D. (2015). Dopamine's actions in primate prefrontal cortex: Challenges for treating cognitive disorders. Pharmacological Reviews, 67(3), 681-696. doi:10.1124/pr.115.010512

Axmacher, N., Cohen, M. X., Fell, J., Haupt, S., Dümpelmann, M., Elger, C. E., . . . Ranganath, C. (2010). Intracranial EEG correlates of expectancy and memory formation in the human hippocampus and nucleus accumbens. Neuron, 65(4), 541-549. doi:http://dx-doiorg.idpproxy.reading.ac.uk/10.1016/j.neuron.2010.02.006

Bach, M. E., Barad, M., Son, H., Zhuo, M., Lu, Y.-F., Shih, R., . . Kandel, E. R. (1999). Age-related defects in spatial memory are correlated with defects in the late 
phase of hippocampal long-term potentiation in vitro and are attenuated by drugs that enhance the cAMP signaling pathway. Proceedings of the National Academy of Sciences of the United States of America, 96(9), 5280-5285.

Bäckman, L., Ginovart, N., Dixon, R. A., Wahlin, T.-B. R., Wahlin, Å., Halldin, C., \& Farde, L. (2000). Age-related cognitive deficits mediated by changes in the striatal dopamine system. American Journal of Psychiatry, 157(4), 635-637. doi:10.1176/ajp.157.4.635

Bäckman, L., Lindenberger, U., Li, S.-C., \& Nyberg, L. (2010). Linking cognitive aging to alterations in dopamine neurotransmitter functioning: Recent data and future avenues. Neuroscience \& Biobehavioral Reviews, 34(5), 670-677. doi:http://dx.doi.org/10.1016/j.neubiorev.2009.12.008

Baer, L. H., Tabri, N., Blair, M., Bye, D., Li, K. Z. H., \& Pushkar, D. (2013). Longitudinal associations of need for cognition, cognitive activity, and depressive symptomatology with cognitive function in recent retirees. The Journals of Gerontology: Series B, 68(5), 655-664. doi:10.1093/geronb/gbs112

Barber, S. J., Opitz, P. C., Martins, B., Sakaki, M., \& Mather, M. (2016). Thinking about a limited future enhances the positivity of younger and older adults' recall: Support for socioemotional selectivity theory. Memory and Cognition, 44(6), 869882. doi:http://dx.doi.org/10.3758/s13421-016-0612-0

Bardo, M. T., Donohew, R. L., \& Harrington, N. G. (1996). Psychobiology of novelty seeking and drug seeking behavior. Behavioural Brain Research, 77(1), 23-43. doi:http://dx-doi-org.idpproxy.reading.ac.uk/10.1016/0166-4328(95)00203-0 
Berlyne, D. E. (1954). A theory of human curiosity. British Journal of Psychology. General Section, 45(3), 180-191. doi:10.1111/j.2044-8295.1954.tb01243.x

Berlyne, D. E. (1970). Novelty, complexity, and hedonic value. Perception \& Psychophysics, 8(5), 279-286. doi:10.3758/BF03212593

Bigham, M. H., \& Lidow, M. S. (1995). Adrenergic and serotonergic receptors in aged monkey neocortex. Neurobiology of Aging, 16(1), 91-104. doi:http://dx.doi.org/10.1016/0197-4580(95)80012-G

Braun, D., Madrigal, J. L. M., \& Feinstein, D. L. (2014). Noradrenergic regulation of glial activation: Molecular mechanisms and therapeutic implications. Current Neuropharmacology, 12(4), 342-352.

doi:10.2174/1570159x12666140828220938

Brodaty, H., Altendorf, A., Withall, A., \& Sachdev, P. (2010). Do people become more apathetic as they grow older? A longitudinal study in healthy individuals. International Psychogeriatrics, 22(3), 426-436. doi:http://dx.doi.org/10.1017/S1041610209991335

Bruder, G. E., Kroppmann, C. J., Kayser, J., Stewart, J. W., McGrath, P. J., \& Tenke, C. E. (2009). Reduced brain responses to novel sounds in depression: P3 findings in a novelty oddball task. Psychiatry Research, 170(2-3), 218-223. doi:http://dx.doi.org/10.1016/i.psychres.2008.10.023

Bunzeck, N., Doeller, C. F., Dolan, R. J., \& Duzel, E. (2012). Contextual interaction between novelty and reward processing within the mesolimbic system. Human Brain Mapping, 33(6), 1309-1324. doi:10.1002/hbm.21288 
Bunzeck, N., \& Düzel, E. (2006). Absolute coding of stimulus novelty in the human substantia nigra/VTA. Neuron, 51(3), 369-379. doi:https://doiorg.idpproxy.reading.ac.uk/10.1016/j.neuron.2006.06.021

Bunzeck, N., Guitart-Masip, M., Dolan, R. J., \& Duzel, E. (2014). Pharmacological dissociation of novelty responses in the human brain. Cerebral Cortex, 24(5), 1351-1360. doi:10.1093/cercor/bhs420

Bunzeck, N., Schütze, H., Stallforth, S., Kaufmann, J., Düzel, S., Heinze, H.-J., \& Düzel, E. (2007). Mesolimbic novelty processing in older adults. Cerebral Cortex, 17(12), 2940-2948. doi:10.1093/cercor/bhm020

Burgdorf, J., \& Panksepp, J. (2006). The neurobiology of positive emotions. Neuroscience \& Biobehavioral Reviews, 30(2), 173-187. doi:https://doi.org/10.1016/j.neubiorev.2005.06.001

Cacioppo, J. T., Hawkley, L. C., \& Thisted, R. A. (2010). Perceived social isolation makes me sad: 5-year cross-lagged analyses of loneliness and depressive symptomatology in the Chicago Health, Aging, and Social Relations Study. Psychology and Aging, 25(2), 453-463. doi:10.1037/a0017216

Carstensen, L. L. (1995). Evidence for a life-span theory of socioemotional selectivity. Current Directions in Psychological Science, 4(5), 151-156.

Carstensen, L. L., Isaacowitz, D. M., \& Charles, S. T. (1999). Taking time seriously. A theory of socioemotional selectivity. American Psychologist, 54(3), 165-181. doi:10.1037/0003-066X.54.3.165

Carstensen, L. L., \& Turk-Charles, S. (1994). The salience of emotion across the adult life span. Psychology and Aging, 9(2), 259-264. 
Caska, C. M., \& Renshaw, K. D. (2013). Personality traits as moderators of the associations between deployment experiences and PTSD symptoms in OEF/OIF service members. Anxiety, Stress, \& Coping, 26(1), 36-51. doi:10.1080/10615806.2011.638053

Chapman, B., Duberstein, P., \& Lyness, J. M. (2007). Personality traits, education, and health-related quality of life among older adult primary care patients. The Journals of Gerontology: Series B, 62(6), P343-P352.

doi:10.1093/geronb/62.6.P343

Chapman, B., Duberstein, P., Tindle, H. A., Sink, K. M., Robbins, J., Tancredi, D. J., \& Franks, P. (2012). Personality predicts cognitive function over 7 years in older persons. The American Journal of Geriatric Psychiatry, 20(7), 612-621.

Chowdhury, R., Guitart-Masip, M., Lambert, C., Dayan, P., Huys, Q., Düzel, E., \& Dolan, R. J. (2013). Dopamine restores reward prediction errors in old age. Nature Neuroscience, 16, 648. doi:10.1038/nn.3364

\section{https://www.nature.com/articles/nn.3364\#supplementary-information}

Clarke, D. E., Ko, J. Y., Lyketsos, C., Rebok, G. W., \& Eaton, W. W. (2010). Apathy and cognitive and functional decline in community-dwelling older adults: results from the Baltimore ECA longitudinal study. International Psychogeriatrics, 22(5), 819829. doi:http://dx.doi.org/10.1017/S1041610209991402

Clewett, D. V., Lee, T.-H., Greening, S., Ponzio, A., Margalit, E., \& Mather, M. (2016). Neuromelanin marks the spot: identifying a locus coeruleus biomarker of cognitive reserve in healthy aging. Neurobiology of Aging, 37(Supplement C), 117-126. doi:https://doi.org/10.1016/i.neurobiolaging.2015.09.019 
Clinton, S. M., Watson, S. J., \& Akil, H. (2014). High novelty-seeking rats are resilient to negative physiological effects of the early life stress. Stress, 17(1), 97-107. doi:10.3109/10253890.2013.850670

Colcombe, S. J., Kramer, A. F., Erickson, K. I., Scalf, P., McAuley, E., Cohen, N. J., . . . Elavsky, S. (2004). Cardiovascular fitness, cortical plasticity, and aging. Proceedings of National Academic Science, 101, 3316-3321.

Collier, T. J., Greene, J. G., Felten, D. L., Stevens, S. Y., \& Collier, K. S. (2004). Reduced cortical noradrenergic neurotransmission is associated with increased neophobia and impaired spatial memory in aged rats. Neurobiology of Aging, 25(2), 209-221. doi:http://dx-doi-org.idpproxy.reading.ac.uk/10.1016/S0197-

\section{$\underline{4580(03) 00042-3}$}

Collier, T. J., Lipton, J., Daley, B. F., Palfi, S., Chu, Y., Sortwell, C., . . Kordower, J. H. (2007). Aging-related changes in the nigrostriatal dopamine system and the response to MPTP in nonhuman primates: Diminished compensatory mechanisms as a prelude to parkinsonism. Neurobiology of Disease, 26(1), 5665. doi:https://doi.org/10.1016/..nbd.2006.11.013

Collins, R. P., Litman, J. A., \& Spielberger, C. D. (2004). The measurement of perceptual curiosity. Personality and Individual Differences, 36(5), 1127-1141. doi:http://dx.doi.org.idpproxy.reading.ac.uk/10.1016/S0191-8869(03)00205-8

Consedine, N. S., \& Moskowitz, J. T. (2007). The role of discrete emotions in health outcomes: A critical review. Applied and Preventive Psychology, 12(2), 59-75. doi:http://dx.doi.org/10.1016/j.appsy.2007.09.001 
Cools, R., Sheridan, M., Jacobs, E., \& D'Esposito, M. (2007). Impulsive Personality Predicts Dopamine-Dependent Changes in Frontostriatal Activity during Component Processes of Working Memory. The Journal of Neuroscience, 27(20), 5506-5514. doi:10.1523/jneurosci.0601-07.2007

Corbett, A., Owen, A., Hampshire, A., Grahn, J., Stenton, R., Dajani, S., . . Ballard, C. (2016). The effect of an online cognitive training package in healthy older adults: An online randomized controlled trial. Journal of the American Medical Directors Association, 16(11), 990-997. doi:10.1016/j.jamda.2015.06.014

Costa, P. T., Herbst, J. H., McCrae, R. R., \& Siegler, I. C. (2000). Personality at midlife: Stability, intrinsic maturation, and response to life events. Assessment, 7(4), 365378. doi:10.1177/107319110000700405

Costa, P. T., McCrae, R. R., \& Holland, J. L. (1984). Personality and vocational interests in an adult sample. Journal of Applied Psychology, 69(3), 390-400.

Czigler, I., Pató, L., Poszet, E., \& Balázs, L. (2006). Age and novelty: Event-related potentials to visual stimuli within an auditory oddball—visual detection task. International Journal of Psychophysiology, 62(2), 290-299. doi:https://doiorg.idpproxy.reading.ac.uk/10.1016/j.ijpsycho.2006.05.008

Daffner, K. R., Chong, H., Riis, J., Rentz, D. M., Wolk, D. A., Budson, A. E., \& Holcomb, P. J. (2007). Cognitive status impacts age-related changes in attention to novel and target events in normal adults. Neuropsychology, 21(3), 291-300.

Daffner, K. R., Ryan, K. K., Williams, D. M., Budson, A. E., Rentz, D. M., Wolk, D. A., \& Holcomb, P. J. (2006a). Age-related differences in attention to novelty among 
cognitively high performing adults. Biological Psychology, 72(1), 67-77. doi:http://dx.doi.org.idpproxy.reading.ac.uk/10.1016/j.biopsycho.2005.07.006

Daffner, K. R., Ryan, K. K., Williams, D. M., Budson, A. E., Rentz, D. M., Wolk, D. A., \& Holcomb, P. J. (2006b). Increased responsiveness to novelty is associated with successful cognitive aging. Journal of Cognitive Neuroscience, 18(10), 17591773. doi:10.1162/jocn.2006.18.10.1759

Daffner, K. R., Scinto, L. F. M., Weintraub, S., Guinessey, J. E., \& Mesulam, M. M. (1992). Diminished curiosity in patients with probable Alzheimer's disease as measured by exploratory eye movements. Neurology, 42(2), 320. doi:10.1212/wnl.42.2.320

Delini-Stula, A., Mogilnicka, E., Hunn, C., \& Dooley, D. J. (1984). Novelty-oriented behavior in the rat after selective damage of locus coeruleus projections by DSP4, a new noradrenergic neurotoxin. Pharmacology Biochemistry and Behavior, 20(4), 613-618. doi:http://dx.doi.org/10.1016/0091-3057(84)90312-5

Dellu, F., Mayo, W., Valleé, M., Le Moal, M., \& Simon, H. (1994). Reactivity to novelty during youth as a predictive factor of cognitive impairment in the elderly: a longitudinal study in rats. Brain Research, 653(1), 51-56. doi:http://dx.doi.org/10.1016/0006-8993(94)90371-9

Denneson, L. M., Smolenski, D. J., Bush, N. E., \& Dobscha, S. K. (2017). Curiosity improves coping efficacy and reduces suicidal ideation severity among military veterans at risk for suicide. Psychiatry Research, 249, 125-131. doi:https://doiorg.idpproxy.reading.ac.uk/10.1016/j.psychres.2017.01.018 
DeSteno, D., Gross, J. J., \& Kubzansky, L. (2013). Affective Science and Health: The Importance of Emotion and Emotion Regulation. Health Psychology, 32(5), 474486.

Devauges, V., \& Sara, S. J. (1990). Activation of the noradrenergic system facilitates an attentional shift in the rat. Behavioural Brain Research, 39(1), 19-28. doi:10.1016/0166-4328(90)90118-x

Ding, Y.-S., Singhal, T., Planeta-Wilson, B., Gallezot, J.-D., Nabulsi, N., Labaree, D., ... Malison, R. T. (2010). PET imaging of the effects of age and cocaine on the norepinephrine transporter in the human brain using $(\mathrm{S}, \mathrm{S})-[11 \mathrm{C}] \mathrm{O}-$ methylreboxetine and HRRT. Synapse, 64(1), 30-38. doi:10.1002/syn.20696

Duberstein, P. R., Sorensen, S., Lyness, J. M., King, D. A., Conwell, Y., Seidlitz, L., \& Caine, E. D. (2003). Personality Is Associated With Perceived Health and Functional Status in Older Primary Care Patients. Psychology and Aging, 18(1), 25-37.

Düzel, E., Bunzeck, N., Guitart-Masip, M., \& Düzel, S. (2010). NOvelty-related motivation of anticipation and exploration by Dopamine (NOMAD): Implications for healthy aging. Neuroscience \& Biobehavioral Reviews, 34(5), 660-669. doi:http://dx.doi.org/10.1016/j.neubiorev.2009.08.006

Eisenberger, N. I., \& Cole, S. W. (2012). Social neuroscience and health: neurophysiological mechanisms linking social ties with physical health. Nature Neuroscience, 15(5), 669-674. doi:http://dx.doi.org/10.1038/nn.3086

Elgueta, D., Aymerich, M. S., Contreras, F., Montoya, A., Celorrio, M., RojoBustamante, E., ... Pacheco, R. (2017). Pharmacologic antagonism of 
dopamine receptor D3 attenuates neurodegeneration and motor impairment in a mouse model of Parkinson's disease. Neuropharmacology, 113(Part A), 110-123. doi:https://doi.org/10.1016/j.neuropharm.2016.09.028

Emborg, M. E., Ma, S. Y., Mufson, E. J., Levey, A. I., Taylor, M. D., Brown, W. D., . . . Kordower, J. H. (1998). Age-related declines in nigral neuronal function correlate with motor impairments in rhesus monkeys. The Journal of Comparative Neurology, 401(2), 253-265. doi:10.1002/(sici)10969861(19981116)401:2<253::aid-cne7>3.0.co;2-x

Engel, S. (2011). Children's need to know: Curiosity in schools. Harvard Educational Review, 81(4), 625-645,784.

Eppinger, B., Schuck, N. W., Nystrom, L. E., \& Cohen, J. D. (2013). Reduced Striatal Responses to Reward Prediction Errors in Older Compared with Younger Adults. The Journal of Neuroscience, 33(24), 9905-9912. doi:10.1523/jneurosci.294212.2013

Fabiani, M., \& Friedman, D. (1995). Changes in brain activity patterns in aging: The novelty oddball. Psychophysiology, 32(6), 579-594. doi:10.1111/j.14698986.1995.tb01234.x

Fastrich, G. M., Kerr, E., Castel, A. D., \& Murayama, K. (in press). The role of curiosity and interest in memory for trivia questions: An investigation with a large-scale database. Motivation Science.

Feinstein, D. L., Heneka, M. T., Gavrilyuk, V., Russo, C. D., Weinberg, G., \& Galea, E. (2002). Noradrenergic regulation of inflammatory gene expression in brain. 
Neurochemistry International, 41(5), 357-365. doi:http://dx-doiorg.idpproxy.reading.ac.uk/10.1016/S0197-0186(02)00049-9

Feist, G. J. (1998). A Meta-Analysis of Personality in Scientific and Artistic Creativity. Personality \& Social Psychology Review (Lawrence Erlbaum Associates), 2(4), 290.

Ferguson, E., \& Bibby, P. A. (2012). Openness to experience and all-cause mortality: A meta-analysis and requivalent from risk ratios and odds ratios. British Journal of Health Psychology, 17(1), 85-102. doi:10.1111/j.2044-8287.2011.02055.x

Ferreira, N., Owen, A., Mohan, A., Corbett, A., \& Ballard, C. (2015). Associations between cognitively stimulating leisure activities, cognitive function and agerelated cognitive decline. International Journal of Geriatric Psychiatry, 30(4), 422430. doi:10.1002/gps.4155

Fredrickson, B. L., \& Carstensen, L. L. (1990). Choosing social partners: How old age and anticipated endings make people more selective. Psychology and Aging, 5(3), 335-347.

Friedman, D., Kazmerski, V. A., \& Cycowicz, Y. M. (1998). Effects of aging on the novelty P3 during attend and ignore oddball tasks. Psychophysiology, 35(5), 508520. doi:10.1017/s0048577298970664

Fritsch, T., Smyth, K. A., Debanne, S. M., Petot, G. J., \& Friedland, R. P. (2005). Participation in novelty-seeking leisure activities and Alzheimer's disease. Journal of Geriatric Psychiatry and Neurology, 18(3), 134-141. doi:10.1177/0891988705277537 
Fung, H. H., Carstensen, L. L., \& Lang, F. R. (2001). Age-related patterns in social networks among European Americans and African Americans: Implications for socioemotional selectivity across the life span. The International Journal of Aging and Human Development, 52(3), 185-206. doi:10.2190/1ABL-9BE5-M0X2-LR9V

Giambra, L. M., Camp, C. J., \& Grodsky, A. (1992). Curiosity and stimulation seeking across the adult life span: Cross-sectional and 6- to 8-year longitudinal findings. Psychology and Aging, 7(1), 150-157.

Gompf, H. S., Mathai, C., Fuller, P. M., Wood, D. A., Pedersen, N. P., Saper, C. B., \& Lu, J. (2010). Locus coeruleus and anterior cingulate cortex sustain wakefulness in a novel environment. The Journal of Neuroscience, 30(43), 14543-14551. doi:10.1523/jneurosci.3037-10.2010

Gottlieb, J., Oudeyer, P.-Y., Lopes, M., \& Baranes, A. (2013). Information-seeking, curiosity, and attention: computational and neural mechanisms. Trends in Cognitive Sciences, 17(11), 585-593.

doi:http://dx.doi.org.idpproxy.reading.ac.uk/10.1016/j.tics.2013.09.001

Greenberg, L. H., \& Weiss, B. (1978). Beta-adrenergic receptors in aged rat brain: Reduced number and capacity of pineal gland to develop supersensitivity. Science, 201(4350), 61-63.

Greenberger, E., O'Connor, J., \& Sorensen, A. (1971). Personality, cognitive, and academic correlates of problem-solving flexibility. Developmental Psychology, $4(3), 416-424$.

Grigsby, J., Kaye, K., Baxter, J., Shetterly, S. M., \& Hamman, R. F. (1998). Executive cognitive abilities and functional status among community-dwelling older persons 
in the San Luis Valley health and aging study. Journal of the American Geriatrics Society, 46(5), 590-596. doi:10.1111/j.1532-5415.1998.tb01075.x

Grossnickle, E. M. (2016). Disentangling curiosity: Dimensionality, definitions, and distinctions from interest in educational contexts. Educational Psychology Review, 28(1), 23-60. doi:http://dx.doi.org/10.1007/s10648-014-9294-y

Gruber, Matthias J., Gelman, Bernard D., \& Ranganath, C. (2014). States of curiosity modulate hippocampus-dependent learning via the dopaminergic circuit. Neuron, 84(2), 486-496. doi:http://dx.doi.org/10.1016/j.neuron.2014.08.060

Harro, J., Oreland, L., Vasar, E., \& Bradwejn, J. (1995). Impaired exploratory behaviour after DSP-4 treatment in rats: implications for the increased anxiety after noradrenergic denervation. European Neuropsychopharmacology, 5(4), 447-455. doi:http://dx-doi-org.idpproxy.reading.ac.uk/10.1016/0924-977X(95)80003-K

Haycock, J. W., Becker, L., Ang, L., Furukawa, Y., Hornykiewicz, O., \& Kish, S. J. (2003). Marked disparity between age-related changes in dopamine and other presynaptic dopaminergic markers in human striatum. Journal of Neurochemistry, 87(3), 574-585. doi:10.1046/j.1471-4159.2003.02017.x

Hemby, S. E., Trojanowski, J. Q., \& Ginsberg, S. D. (2003). Neuron-specific age-related decreases in dopamine receptor subtype mRNAs. The Journal of Comparative Neurology, 456(2), 176-183. doi:10.1002/cne.10525

Heneka, M. T., Nadrigny, F., Regen, T., Martinez-Hernandez, A., Dumitrescu-Ozimek, L., Terwel, D., .. Kummer, M. P. (2010). Locus ceruleus controls Alzheimer's disease pathology by modulating microglial functions through norepinephrine. 
Proceedings of the National Academy of Sciences, 107(13), 6058-6063.

doi:10.1073/pnas.0909586107

Hidi, S., \& Renninger, K. A. (2006). The Four-Phase Model of Interest Development.

Educational Psychologist, 41(2), 111-127. doi:10.1207/s15326985ep4102_4

Hoffing, C. R., \& Seitz, A. R. (2015). Pupillometry as a glimpse into the neurochemical basis of human memory encoding. Journal of Cognitive Neuroscience, 27(4), 765-774. doi:10.1162/jocn_a_00749

Hogan, M. J., Staff, R. T., Bunting, B. P., Deary, I. J., \& Whalley, L. J. (2012). Openness to experience and activity engagement facilitate the maintenance of verbal ability in older adults. Psychology and Aging, 27(4), 849.

Izard, C. E. (2009). Emotion theory and research: highlights, unanswered questions, and emerging issues. Annual Review of Psychology, 60, 1-25.

doi:10.1146/annurev.psych.60.110707.163539

Jayanthi, L. D., \& Ramamoorthy, S. (2005). Regulation of monoamine transporters: Influence of psychostimulants and therapeutic antidepressants. The AAPS Journal, 7(3), E728-E738. doi:10.1208/aapsj070373

Jepma, M., Verdonschot, R., van Steenbergen, H., Rombouts, S., \& Nieuwenhuis, S. (2012). Neural mechanisms underlying the induction and relief of perceptual curiosity. Frontiers in Behavioral Neuroscience, 6(5).

doi:10.3389/fnbeh.2012.00005

Jonassaint, C. R., Boyle, S. H., Williams, R. B., Mark, D. B., Siegler, I. C., \& Barefoot, J. C. (2007). Facets of openness predict mortality in patients with cardiac disease. Psychosomatic Medicine, 69(4), 319-322. doi:10.1097/PSY.0b013e318052e27d 
Jones, B. E., \& Moore, R. Y. (1977). Ascending projections of the locus coeruleus in the rat. II. Autoradiographic study. Brain Research, 127(1), 23-53. doi:http://dx.doi.org/10.1016/0006-8993(77)90378-X

Jones, R. S. G., \& Olpe, H.-R. (1984). Multiple changes in the sensitivity of cingulate cortical neurones to putative neurotransmitters in ageing rats: Substance $P$, acetylcholine and noradrenaline. Neuroscience Letters, 50(1), 31-36. doi:http://dx.doi.org/10.1016/0304-3940(84)90457-9

Jones, R. S. G., \& Olpe, H. R. (1983). Altered sensitivity of forebrain neurones to iontophoretically applied noradrenaline in aging rats. Neurobiology of Aging, 4(1), 97-99. doi:http://dx.doi.org/10.1016/0197-4580(83)90060-X

Joshi, S., Li, Y., Kalwani, R. M., \& Gold, J. I. (2016). Relationships between pupil diameter and neuronal activity in the locus coeruleus, colliculi, and cingulate cortex. Neuron, 89(1), 221-234. doi:https://doi.org/10.1016/..neuron.2015.11.028

Kaasinen, V., \& Rinne, J. O. (2002). Functional imaging studies of dopamine system and cognition in normal aging and Parkinson's disease. Neuroscience \& Biobehavioral Reviews, 26(7), 785-793. doi:http://dx-doiorg.idpproxy.reading.ac.uk/10.1016/S0149-7634(02)00065-9

Kang, M. J., Hsu, M., Krajbich, I. M., Loewenstein, G., McClure, S. M., Wang, J. T.-y., \& Camerer, C. F. (2009). The wick in the candle of learning: Epistemic curiosity activates reward circuitry and enhances memory. Psychological Science, 20(8), 963-973.

Kashdan, T. B., Gallagher, M. W., Silvia, P. J., Winterstein, B. P., Breen, W. E., Terhar, D., \& Steger, M. F. (2009). The curiosity and exploration inventory-II: 
Development, factor structure, and psychometrics. Journal of Research in Personality, 43(6), 987-998. doi:https://doi.org/10.1016/j.jrp.2009.04.011

Kashdan, T. B., Rose, P., \& Fincham, F. D. (2004). Curiosity and exploration:

Facilitating positive subjective experiences and personal growth opportunities. Journal of Personality Assessment, 82(3), 291-305.

Kashdan, T. B., \& Silvia, P. J. (2009). Curiosity and interest: The benefits of thriving on novelty and challenge. Oxford handbook of positive psychology, 2, 367-374.

Kashdan, T. B., \& Steger, M. F. (2007). Curiosity and pathways to well-being and meaning in life: Traits, states, and everyday behaviors. Motivation and Emotion, 31(3), 159-173. doi:http://dx.doi.org/10.1007/s11031-007-9068-7

Kellough, J. L., \& Knight, B. G. (2012). Positivity effects in older adults' perception of facial emotion: The role of future time perspective. The Journals of Gerontology Series B: Psychological Sciences and Social Sciences, 67B(2), 150-158. doi:10.1093/geronb/gbr079

Kidd, C., \& Hayden, Benjamin Y. (2015). The Psychology and Neuroscience of Curiosity. Neuron, 88(3), 449-460. doi:10.1016/j.neuron.2015.09.010

Klahr, D., Zimmerman, C., \& Jirout, J. (2011). Educational interventions to advance children's scientific thinking. Science, 333(6045), 971-975.

Krebs, R. M., Heipertz, D., Schuetze, H., \& Duzel, E. (2011). Novelty increases the mesolimbic functional connectivity of the substantia nigra/ventral tegmental area (SN/VTA) during reward anticipation: Evidence from high-resolution fMRI. Neuroimage, 58(2), 647-655. doi:http://dx.doi.org/10.1016/j.neuroimage.2011.06.038 
Krebs, R. M., Schott, B. H., \& Düzel, E. (2009). Personality Traits Are Differentially Associated with Patterns of Reward and Novelty Processing in the Human Substantia Nigra/Ventral Tegmental Area. Biological Psychiatry, 65(2), 103-110. doi:https://doi-org.idpproxy.reading.ac.uk/10.1016/j.biopsych.2008.08.019

Kubzansky, L. D., Cole, S. R. P., Kawachi, I. P., Vokonas, P. M. D., \& Sparrow, D. D. (2006). Shared and unique contributions of anger, anxiety, and depression to coronary heart disease: A prospective study in the normative aging study. Annals of Behavioral Medicine, 31(1), 21-29. doi:http://dx.doi.org/10.1207/s15324796abm3101 5

Kubzansky, L. D., Koenen, K. C., Jones, C., \& Eaton, W. W. (2009). A prospective study of posttraumatic stress disorder symptoms and coronary heart disease in women. Health Psychology, 28(1), 125-130.

Kuo, H.-K., Yen, C.-J., Chang, C.-H., Kuo, C.-K., Chen, J.-H., \& Sorond, F. (2005). Relation of C-reactive protein to stroke, cognitive disorders, and depression in the general population: systematic review and meta-analysis. The Lancet Neurology, 4(6), 371-380. doi:https://doi.org/10.1016/S1474-4422(05)70099-5 Lanctôt, K. L., Agüera-Ortiz, L., Brodaty, H., Francis, P. T., Geda, Y. E., Ismail, Z., . . . Abraham, E. H. (2017). Apathy associated with neurocognitive disorders: Recent progress and future directions. Alzheimer's \& Dementia, 13(1), 84-100. doi:https://doi.org/10.1016/j.jalz.2016.05.008

Lang, F. R., \& Carstensen, L. L. (1994). Close emotional relationships in late life: Further support for proactive aging in the social domain. Psychology and Aging, 9(2), 315-324. 
Lang, F. R., \& Carstensen, L. L. (2002). Time counts: Future time perspective, goals, and social relationships. Psychology and Aging, 17(1), 125-139. doi:10.1037/0882-7974.17.1.125

Lavin, C., San Martín, R., \& Rosales Jubal, E. (2014). Pupil dilation signals uncertainty and surprise in a learning gambling task. Frontiers in Behavioral Neuroscience, 7(218). doi:10.3389/fnbeh.2013.00218

Lawton, M. P., Kleban, M. H., Rajagopal, D., \& Dean, J. (1992). Dimensions of affective experience in three age groups. Psychology and Aging, 7(2), 171-184.

Legault, M., \& Wise, R. A. (2001). Novelty-evoked elevations of nucleus accumbens dopamine: dependence on impulse flow from the ventral subiculum and glutamatergic neurotransmission in the ventral tegmental area. European Journal of Neuroscience, 13(4), 819-828. doi:10.1046/j.0953-816x.2000.01448.x

Levy, M. L., Cummings, J. L., Fairbanks, L. A., Masterman, D., Miller, B. L., Craig, A. H., . . Litvan, I. (1998). Apathy is not depression. The Journal of Neuropsychiatry and Clinical Neurosciences, 10(3), 314-319.

Li, S., Cullen, W. K., Anwyl, R., \& Rowan, M. J. (2003). Dopamine-dependent facilitation of LTP induction in hippocampal CA1 by exposure to spatial novelty. Nature Neuroscience, 6(5), 526-531. doi:http://dx.doi.org/10.1038/nn1049

Li, S., Jin, M., Zhang, D., Yang, T., Koeglsperger, T., Fu, H., \& Selkoe, Dennis J. (2013). Environmental novelty activates $\beta 2$-adrenergic signaling to prevent the impairment of hippocampal LTP by A oligomers. Neuron, 77(5), 929-941. doi:http://dx.doi.org.idpproxy.reading.ac.uk/10.1016/j.neuron.2012.12.040 
Lisman, J. E., \& Grace, A. A. (2005). The hippocampal-VTA loop: controlling the entry of information into long-term memory. Neuron, 46(5), 703-713.

Litman, J. A. (2008). Interest and deprivation factors of epistemic curiosity. Personality and Individual Differences, 44(7), 1585-1595.

doi:http://dx.doi.org.idpproxy.reading.ac.uk/10.1016/i.paid.2008.01.014

Litman, J. A., \& Spielberger, C. D. (2003). Measuring epistemic curiosity and its diversive and specific components. Journal of Personality Assessment, 80(1), 75-86.

Ljungberg, T., Apicella, P., \& Schultz, W. (1992). Responses of monkey dopamine neurons during learning of behavioral reactions. Journal of Neurophysiology, $67(1), 145-163$.

Löckenhoff, C. E., \& Carstensen, L. L. (2004). Socioemotional selectivity theory, aging, and health: The increasingly delicate balance between regulating emotions and making tough choices. Journal of Personality, 72(6), 1395-1424.

doi:10.1111/j.1467-6494.2004.00301.x

Löckenhoff, C. E., \& Carstensen, L. L. (2007). Aging, emotion, and health-related decision strategies: Motivational manipulations can reduce age differences. Psychology and Aging, 22(1), 134-146. doi:10.1037/0882-7974.22.1.134

Loewenstein, G. (1994). The psychology of curiosity: A review and reinterpretation. Psychological Bulletin, 116(1), 75-98.

Low, K. S. D., Yoon, M., Roberts, B. W., \& Rounds, J. (2005). The stability of vocational interests from early adolescence to middle adulthood: A quantitative review of longitudinal studies. Psychological Bulletin, 131(5), 713-737. 
MacDonald, S. W. S., Karlsson, S., Rieckmann, A., Nyberg, L., \& Bäckman, L. (2012). Aging-related increases in behavioral variability: Relations to losses of dopamine D1 receptors. The Journal of Neuroscience, 32(24), 8186-8191. doi:10.1523/jneurosci.5474-11.2012

Marin, R. S., Firinciogullari, S., \& Biedrzycki, R. C. (1993). The sources of convergence between measures of apathy and depression. Journal of Affective Disorders, 28(2), 117-124. doi:http://dx-doi-org.idpproxy.reading.ac.uk/10.1016/0165$\underline{0327(93) 90040-Q}$

Martin, S. B., Covell, D. J., Joseph, J. E., Chebrolu, H., Smith, C. D., Kelly, T. H., . . . Gold, B. T. (2007). Human experience seeking correlates with hippocampus volume: Convergent evidence from manual tracing and voxel-based morphometry. Neuropsychologia, 45(12), 2874-2881. doi:https://doiorg.idpproxy.reading.ac.uk/10.1016/j.neuropsychologia.2007.05.009

Mather, M., Clewett, D., Sakaki, M., \& Harley, C. W. (2016). Norepinephrine ignites local hotspots of neuronal excitation: How arousal amplifies selectivity in perception and memory. Behavioral and Brain Sciences, 39.

doi:10.1017/S0140525X15000667

Mather, M., \& Harley, C. W. (2016). The locus coeruleus: Essential for maintaining cognitive function and the aging brain. Trends in Cognitive Sciences, 20(3), 214226. doi:http://dx-doi-org.idpproxy.reading.ac.uk/10.1016/j.tics.2016.01.001

Mayer, J. S., Kim, J., \& Park, S. (2011). Enhancing visual working memory encoding: The role of target novelty. Visual Cognition, 19(7), 863-885. doi:10.1080/13506285.2011.594459 
McAfoose, J., \& Baune, B. T. (2009). Evidence for a cytokine model of cognitive function. Neuroscience \& Biobehavioral Reviews, 33(3), 355-366. doi:https://doi.org/10.1016/j.neubiorev.2008.10.005

McCrae, R. R., \& Costa, P. T., Jr. (1987). Validation of the five-factor model of personality across instruments and observers. Journal of Personality and Social Psychology, 52(1), 81-90.

McCrae, R. R., Costa, P. T., Jr., de Lima, M. P., Simoes, A., Ostendorf, F., Angleitner, A., , . Piedmont, R. L. (1999). Age differences in personality across the adult life span: Parallels in five cultures. Developmental Psychology, 35(2), 466-477.

McCrae, R. R., Costa, P. T., Jr., Ostendorf, F., Angleitner, A., Hrebickova, M., Avia, M. D., ... Smith, P. B. (2000). Nature over nurture: Temperament, personality, and life span development. Journal of Personality and Social Psychology, 78(1), 173186.

McGillivray, S., Murayama, K., \& Castel, A. D. (2015). Thirst for knowledge: The effects of curiosity and interest on memory in younger and older adults. Psychology and Aging, 30(4), 835-841.

Míguez, J. M., Aldegunde, M., Paz-Valiñas, L., Recio, J., \& Sánchez-Barceló, E. (1999). Selective changes in the contents of noradrenaline, dopamine and serotonin in rat brain areas during aging. Journal of Neural Transmission, 106(11), 10891098. doi:10.1007/s007020050225

Mikels, J. A., Löckenhoff, C. E., Maglio, S. J., Carstensen, L. L., Goldstein, M. K., \& Garber, A. (2010). Following your heart or your head: Focusing on emotions versus information differentially influences the decisions of younger and older 
adults. Journal of Experimental Psychology: Applied, 16(1), 87-95.

doi:10.1037/0882 -7974.22.4.796

Miller, A. H., Maletic, V., \& Raison, C. L. (2009). Inflammation and its discontents: The role of cytokines in the pathophysiology of major depression. Biological Psychiatry, 65(9), 732-741. doi:https://doi.org/10.1016/j.biopsych.2008.11.029

Mitchell, K. J., Johnson, M. K., Raye, C. L., \& D'Esposito, M. (2000). fMRI evidence of age-related hippocampal dysfunction in feature binding in working memory. Cognitive Brain Research, 10(1-2), 197-206.

Moncada, D., \& Viola, H. (2007). Induction of long-term memory by exposure to novelty requires protein synthesis: Evidence for a behavioral tagging. The Journal of Neuroscience, 27(28), 7476-7481. doi:10.1523/jneurosci.1083-07.2007

Moore, T. L., Schettler, S. P., Killiany, R. J., Herndon, J. G., Luebke, J. I., Moss, M. B., \& Rosene, D. L. (2005). Cognitive impairment in aged rhesus monkeys associated with monoamine receptors in the prefrontal cortex. Behavioural Brain Research, 160(2), 208-221. doi:http://dx.doi.org/10.1016/j.bbr.2004.12.003

Mroczek, D. K., \& Kolarz, C. M. (1998). The effect of age on positive and negative affect: A developmental perspective on happiness. Journal of Personality and Social Psychology, 75(5), 1333-1349. doi:10.1177/014662167700100306]197910129-00110.1177/014662167700100306

Murphy, P. R., O'Connell, R. G., O'Sullivan, M., Robertson, I. H., \& Balsters, J. H. (2014). Pupil diameter covaries with BOLD activity in human locus coeruleus. Human Brain Mapping, 35(8), 4140-4154. doi:10.1002/hbm.22466 
Murphy, P. R., Robertson, I. H., Balsters, J. H., \& O'Connell, R. G. (2011). Pupillometry and P3 index the locus coeruleus-noradrenergic arousal function in humans. Psychophysiology, 48(11), 1532-1543. doi:10.1111/j.1469-8986.2011.01226.x

Mussel, P. (2013). Introducing the construct curiosity for predicting job performance. Journal of Organizational Behavior, 34(4), 453-472. doi:10.1002/job.1809

Nagel, I., Chicherio, C., Li, S.-C., Von Oertzen, T., Sander, T., Villringer, A., . . . Lindenberger, U. (2008). Human aging magnifies genetic effects on executive functioning and working memory. Frontiers in Human Neuroscience, 2(1). doi:10.3389/neuro.09.001.2008

Nassar, M. R., Bruckner, R., Gold, J. I., Li, S.-C., Heekeren, H. R., \& Eppinger, B. (2016). Age differences in learning emerge from an insufficient representation of uncertainty in older adults. Nature Communications, 7, 11609. doi:http://dx.doi.org/10.1038/ncomms11609

Nassar, M. R., Rumsey, K. M., Wilson, R. C., Parikh, K., Heasly, B., \& Gold, J. I. (2012). Rational regulation of learning dynamics by pupil-linked arousal systems. Nature Neuroscience, 15(7), 1040-1046. doi:10.1038/nn.3130

Nieuwenhuis, S., Aston-Jones, G., \& Cohen, J. D. (2005). Decision making, the P3, and the locus coeruleus-norepinephrine system. Psychological Bulletin, 131(4), 510532.

Nyberg, L., Salami, A., Andersson, M., Eriksson, J., Kalpouzos, G., Kauppi, K., . . . Nilsson, L.-G. (2010). Longitudinal evidence for diminished frontal cortex function in aging. Proceedings of the National Academy of Sciences, 107(52), 2268222686. doi:10.1073/pnas.1012651108 
O'Donnell, J., Zeppenfeld, D., McConnell, E., Pena, S., \& Nedergaard, M. (2012).

Norepinephrine: a neuromodulator that boosts the function of multiple cell types to optimize CNS performance. Neurochemical Research, 37. doi:10.1007/s11064-012-0818-x

Olpe, H.-R., \& Steinmann, M. W. (1982). Age-related decline in the activity of noradrenergic neurons of the rat locus coeruleus. Brain Research, 251(1), 174176. doi:http://dx.doi.org/10.1016/0006-8993(82)91287-2

Olson, K., Camp, C., \& Fuller, D. (1984). Curiosity and need for cognition. Psychological Reports, 54(1), 71-74. doi:10.2466/pr0.1984.54.1.71

Oudeyer, P. Y., Gottlieb, J., \& Lopes, M. (2016). Intrinsic motivation, curiosity, and learning. Progress in Brain Research, 229, 257-284. doi:http://dx.doi.org/10.1016/bs.pbr.2016.05.005

Papenberg, G., Lindenberger, U., \& Bäckman, L. (2015). Aging-related magnification of genetic effects on cognitive and brain integrity. Trends in Cognitive Sciences, 19(9), 506-514. doi:http://dx-doi-

\section{org.idpproxy.reading.ac.uk/10.1016/j.tics.2015.06.008}

Park, N., Peterson, C., \& Seligman, M. E. P. (2004). Strength of character and wellbeing. Journal of Social and Clinical Psychology, 23(5), 603-619.

Payzan-LeNestour, E., Dunne, S., Bossaerts, P., \& O’Doherty, J. P. (2013). The neural representation of unexpected uncertainty during value-based decision making. Neuron, 79(1), 191-201. doi:http://dx.doi.org.idpproxy.reading.ac.uk/10.1016/j.neuron.2013.04.037 
Pedersen, K. F., Alves, G., Aarsland, D., \& Larsen, J. P. (2009). Occurrence and risk factors for apathy in Parkinson disease: a 4-year prospective longitudinal study. Journal of Neurology, Neurosurgery and Psychiatry, 80(11), 1279. doi:http://dx.doi.org/10.1136/jnnp.2008.170043

Peterson, C., Park, N., \& Seligman, M. E. P. (2006). Greater strengths of character and recovery from illness. The Journal of Positive Psychology, 1(1), 17-26. doi:10.1080/17439760500372739

Piazza, P. V., Rougé-Pont, F., Deminière, J. M., Kharoubi, M., Le Moal, M., \& Simon, H. (1991). Dopaminergic activity is reduced in the prefrontal cortex and increased in the nucleus accumbens of rats predisposed to develop amphetamine selfadministration. Brain Research, 567(1), 169-174. doi:http://dx.doi.org/10.1016/0006-8993(91)91452-7

Pineda, J. A., Foote, S., \& Neville, H. (1989). Effects of locus coeruleus lesions on auditory, long-latency, event- related potentials in monkey. The Journal of Neuroscience, 9(1), 81-93.

Pineda, J. A., \& Westerfield, M. (1993). Monkey P3 in an "oddball” paradigm: Pharmacological support for multiple neural sources. Brain Research Bulletin, 31(6), 689-696. doi:http://dx.doi.org/10.1016/0361-9230(93)90142-X

Pontifex, M. B., Hillman, C. H., \& Polich, J. (2009). Age, physical fitness, and attention: P3a and P3b. Psychophysiology, 46(2), 379-387. doi:10.1111/j.14698986.2008.00782.x

Raz, N., Ghisletta, P., Rodrigue, K. M., Kennedy, K. M., \& Lindenberger, U. (2010). Trajectories of brain aging in middle-aged and older adults: Regional and 
individual differences. Neuroimage, 51(2), 501-511.

doi:https://doi.org/10.1016/j.neuroimage.2010.03.020

Raz, N., Rodrigue, K. M., Kennedy, K. M., Head, D., Gunning-Dixon, F., \& Acker, J. D. (2003). Differential aging of the human striatum: Longitudinal evidence. American Journal of Neuroradiology, 24(9), 1849-1856.

Rebec, G. V., Christensen, J. R. C., Guerra, C., \& Bardo, M. T. (1997). Regional and temporal differences in real-time dopamine efflux in the nucleus accumbens during free-choice novelty. Brain Research, 776(1-2), 61-67. doi:https://doiorg.idpproxy.reading.ac.uk/10.1016/S0006-8993(97)01004-4

Rebec, G. V., Grabner, C. P., Johnson, M., Pierce, R. C., \& Bardo, M. T. (1996).

Transient increases in catecholaminergic activity in medial prefrontal cortex and nucleus accumbens shell during novelty. Neuroscience, 76(3), 707-714. doi:https://doi-org.idpproxy.reading.ac.uk/10.1016/S0306-4522(96)00382-X

Reeves, S., Bench, C., \& Howard, R. (2002). Ageing and the nigrostriatal dopaminergic system. International Journal of Geriatric Psychiatry, 17(4), 359-370. doi:10.1002/gps.606

Renner, B. (2006). Curiosity about people: the development of a social curiosity measure in adults. Journal of Personality Assessment, 87(3), 305-316.

Renninger, K. A., \& Hidi, S. (2016). The power of interest for motivation and learning. New York: Routledge.

Richman, L. S., Kubzansky, L., Maselko, J., Kawachi, I., Choo, P., \& Bauer, M. (2005). Positive emotion and health: Going beyond the negative. Health Psychology, 24(4), 422-429. 
Rinne, J. O., Hietala, J., Ruotsalainen, U., Säkö, E., Laihinen, A., Någren, K., . . . Syvälahti, E. (1993). Decrease in human striatal dopamine D2 receptor density with age: A PET study with [11C]raclopride. Journal of Cerebral Blood Flow \& Metabolism, 13(2), 310-314. doi:10.1038/jcbfm.1993.39

Rinne, J. O., Lönnberg, P., \& Marjamäki, P. (1990). Age-dependent decline in human brain dopamine D1 and D2 receptors. Brain Research, 508(2), 349-352. doi:https://doi.org/10.1016/0006-8993(90)90423-9

Robert, P. H. M. D., Berr, C. M. D., Volteau, M. P., Bertogliati-Fileau, C. P., Benoit, M. M. D., Guerin, O. M. D., . . Dubois, B. M. D. (2008). Importance of lack of interest in patients with Mild Cognitive Impairment. The American Journal of Geriatric Psychiatry, 16(9), 770-776.

Robertson, I. H. (2013). A noradrenergic theory of cognitive reserve: implications for Alzheimer's disease. Neurobiology of Aging, 34(1), 298-308. doi:http://dx.doi.org/10.1016/j.neurobiolaging.2012.05.019

Robinson, O. C., Demetre, J. D., \& Litman, J. A. (2017). Adult life stage and crisis as predictors of curiosity and authenticity. International Journal of Behavioral Development, 41(3), 426-431. doi:10.1177/0165025416645201

Romaniuk, J. G., \& Romaniuk, M. (1982). Participation Motives of Older Adults in Higher Education: The Elderhostel Experience1. The Gerontologist, 22(4), 364-368. doi:10.1093/geront/22.4.364

Roosevelt, E. (1961). The autography of Eleanor Roosevelt. New York, NY: HarperCollins Publishers. 
Sakaki, M., Fryer, K., \& Mather, M. (2014). Emotion strengthens high-priority memory traces but weakens low-priority memory traces. Psychological Science, 25(2), 387-395. doi:10.1177/0956797613504784

Salthouse, T. A. (2010). Selective review of cognitive aging. Journal of International Neuropsychological Society, 16, 754-760. doi:10.1017/S1355617710000706

Sara, S. J., Dyon-Laurent, C., \& Hervé, A. (1995). Novelty seeking behavior in the rat is dependent upon the integrity of the noradrenergic system. Cognitive Brain Research, 2(3), 181-187. doi:http://dx.doi.org/10.1016/0926-6410(95)90007-1

Scholz, J., Allemang-Grand, R., Dazai, J., \& Lerch, J. P. (2015). Environmental enrichment is associated with rapid volumetric brain changes in adult mice. Neuroimage, 109, 190-198. doi:http://dx.doi.org/10.1016/j.neuroimage.2015.01.027

Schomaker, J., \& Meeter, M. (2015). Short- and long-lasting consequences of novelty, deviance and surprise on brain and cognition. Neuroscience \& Biobehavioral Reviews, 55, 268-279. doi:https://doi-

\section{org.idpproxy.reading.ac.uk/10.1016/j.neubiorev.2015.05.002}

Schomaker, J., van Bronkhorst, M. L. V., \& Meeter, M. (2014). Exploring a novel environment improves motivation and promotes recall of words. Frontiers in Psychology, 5(918). doi:10.3389/fpsyg.2014.00918

Schott, B. H., Niehaus, L., Wittmann, B. C., Schütze, H., Seidenbecher, C. I., Heinze, H.-J., \& Düzel, E. (2007). Ageing and early-stage Parkinson's disease affect separable neural mechanisms of mesolimbic reward processing. Brain, 130(9), 2412-2424. doi:10.1093/brain/awm147 
Sharp, E. S., Reynolds, C. A., Pedersen, N. L., \& Gatz, M. (2010). Cognitive engagement and cognitive aging: Is openness protective? Psychology and Aging, 25(1), 60-73.

Silvia, P. J. (2005). What is interesting? Exploring the appraisal structure of interest. Emotion, 5(1), 89-102. doi:10.1037/1528-3542.5.1.89

Silvia, P. J. (2008). Interest: The curious emotion. Current Directions in Psychological Science, 17(1), 57-60. doi:10.1111/j.1467-8721.2008.00548.x

Simon, H. A. (2001). "Seek and ye shall find": How curiosity engenders discovery. In K. Crowley, C. D. Schunn, \& T. Okada (Eds.), Designing for science: Implications from everyday, classroom, and professional settings (pp. 5-20). Mahwah, New Jersey: Lawrence Erlbaum Associates.

Smock, C. D., \& Holt, B. G. (1962). Children's reactions to novelty: An experimental study of "curiosity motivation". Child Development, 33(3), 631-642. doi:10.2307/1126663

Sörensen, S., Duberstein, P. R., Chapman, B., Lyness, J. M., \& Pinquart, M. (2008). How are personality traits related to preparation for future care needs in older adults? The Journals of Gerontology: Series B, 63(6), P328-P336. doi:10.1093/geronb/63.6.P328

Starkstein, S. E., Jorge, R., Mizrahi, R., \& Robinson, R. G. (2006). A prospective longitudinal study of apathy in Alzheimer's disease. Journal of Neurology, Neurosurgery and Psychiatry, 77(1), 8. doi:http://dx.doi.org/10.1136/jnnp.2005.069575 
Stedenfeld, K. A., Clinton, S. M., Kerman, I. A., Akil, H., Watson, S. J., \& Sved, A. F. (2011). Novelty-seeking behavior predicts vulnerability in a rodent model of depression. Physiology \& Behavior, 103(2), 210-216. doi:http://dx-doiorg.idpproxy.reading.ac.uk/10.1016/j.physbeh.2011.02.001

Steenkamp, J.-B. E. M., \& Baumgartner, H. (1992). The role of optimum stimulation level in exploratory consumer behavior. Journal of Consumer Research, 19(3), 434-448. doi:10.1086/209313

Steiger, T. K., Weiskopf, N., \& Bunzeck, N. (2016). Iron level and myelin content in the ventral striatum predict memory performance in the aging brain. The Journal of Neuroscience, 36(12), 3552-3558. doi:10.1523/jneurosci.3617-15.2016

Straube, T., Korz, V., Balschun, D., \& Frey, U. J. (2003). Requirement of $\beta$-adrenergic receptor activation and protein synthesis for LTP-reinforcement by novelty in rat dentate gyrus. The Journal of Physiology, 552(3), 953-960. doi:10.1113/jphysiol.2003.049452

Sullivan, R. M., \& Dufresne, M. M. (2006). Mesocortical dopamine and HPA axis regulation: Role of laterality and early environment. Brain Research, 1076(1), 4959. doi:http://dx-doi-org.idpproxy.reading.ac.uk/10.1016/j.brainres.2005.12.100

Sutin, A. R., Terracciano, A., Kitner-Triolo, M. H., Uda, M., Schlessinger, D., \& Zonderman, A. B. (2011). Personality traits prospectively predict verbal fluency in a lifespan sample. Psychology and Aging, 26(4), 994-999.

Swan, G. E., \& Carmelli, D. (1996). Curiosity and mortality in aging adults: A 5-Year follow-up of the Western collaborative group study. Psychology and Aging, 11(3), 449-453. 
Szot, P., Franklin, A., Miguelez, C., Wang, Y., Vidaurrazaga, I., Ugedo, L., . . Raskind, M. A. (2016). Depressive-like behavior observed with a minimal loss of locus coeruleus (LC) neurons following administration of 6-hydroxydopamine is associated with electrophysiological changes and reversed with precursors of norepinephrine. Neuropharmacology, 101, 76-86.

\section{doi:http://dx.doi.org/10.1016/j.neuropharm.2015.09.003}

Tolea, M. I., Ferrucci, L., Costa, P. T., Faulkner, K., Rosano, C., Satterfield, S., . . . Simonsick, E. M. (2012). Personality and reduced incidence of walking limitation in late life: Findings from the health, aging, and body composition study. The Journals of Gerontology: Series B, 67(6), 712-719. doi:10.1093/geronb/gbs001

Torres-Rosas, R., Yehia, G., Peña, G., Mishra, P., del Rocio Thompson-Bonilla, M., Moreno-Eutimio, M. A., . . Ulloa, L. (2014). Dopamine mediates vagal modulation of the immune system by electroacupuncture. Nature Medicine, 20, 291. doi:10.1038/nm.3479

\section{https://www.nature.com/articles/nm.3479\#supplementary-information}

Turiano, N. A., Avron Spiro, I., \& Mroczek, D. K. (2012). Openness to experience and mortality in men. Journal of Aging and Health, 24(4), 654-672. doi:doi:10.1177/0898264311431303

Usher, M., Cohen, J. D., Servan-Schreiber, D., Rajkowski, J., \& Aston-Jones, G. (1999). The role of locus coeruleus in the regulation of cognitive performance. Science, 283(5401), 549-554. 
Van Waas, M., \& Soffié, M. (1996). Differential environmental modulations on locomotor activity, exploration and spatial behaviour in young and old rats. Physiology \& Behavior, 59(2), 265-271. doi:http://dx.doi.org/10.1016/0031-9384(95)02151-5

Vankov, A., Hervé-Minvielle, A., \& Sara, S. J. (1995). Response to novelty and its rapid habituation in locus coeruleus neurons of the freely exploring rat. European Journal of Neuroscience, 7(6), 1180-1187. doi:10.1111/j.1460-

9568.1995.tb01108.x

Vittersø, J. (2003). Flow versus life satisfaction: A projective use of cartoons to illustrate the difference between the evaluation approach and the intrinsic motivation approach to subjective quality of life. Journal of Happiness Studies, 4(2), 141167. doi:http://dx.doi.org/10.1023/A:1024413112234

Vittersø, J., \& Søholt, Y. (2011). Life satisfaction goes with pleasure and personal growth goes with interest: Further arguments for separating hedonic and eudaimonic well-being. The Journal of Positive Psychology, 6(4), 326-335. doi:10.1080/17439760.2011.584548

Von Stumm, S., Hell, B., \& Chamorro-Premuzic, T. (2011). The hungry mind: Intellectual curiosity is the third pillar of academic performance. Perspectives on Psychological Science, 6(6), 574-588.

Walhovd, K. B., Fjell, A. M., Reinvang, I., Lundervold, A., Dale, A. M., Eilertsen, D. E., ... Fischl, B. (2005). Effects of age on volumes of cortex, white matter and subcortical structures. Neurobiology of Aging, 26(9), 1261-1270. doi:http://dx-doiorg.idpproxy.reading.ac.uk/10.1016/j.neurobiolaging.2005.05.020 
Wetzel, N., Widmann, A., \& Schroger, E. (2012). Distraction and Facilitation-Two Faces of the Same Coin? Journal of Experimental Psychology: Human Perception and Performance, 38(3), 664-674.

Williams, P. G., Rau, H. K., Cribbet, M. R., \& Gunn, H. E. (2009). Openness to Experience and stress regulation. Journal of Research in Personality, 43(5), 777784. doi:http://dx-doi-org.idpproxy.reading.ac.uk/10.1016/j.jrp.2009.06.003

Williams, P. G., Suchy, Y., \& Kraybill, M. L. (2013). Preliminary evidence for low openness to experience as a pre-clinical marker of incipient cognitive decline in older adults. Journal of Research in Personality, 47(6), 945-951. doi:http://dx-doiorg.idpproxy.reading.ac.uk/10.1016/i.jrp.2013.09.006

Wilson, R. S., Nag, S., Boyle, P. A., Hizel, L. P., Yu, L., Buchman, A. S., . . Bennett, D. A. (2013). Neural reserve, neuronal density in the locus ceruleus, and cognitive decline. Neurology, 80, 1202-1208. doi:10.1212/WNL.0b013e3182897103

Wittmann, B. C., Bunzeck, N., Dolan, R. J., \& Düzel, E. (2007). Anticipation of novelty recruits reward system and hippocampus while promoting recollection. Neuroimage, 38(1), 194-202. doi:https://doi.org/10.1016/i.neuroimage.2007.06.038

Wittmann, B. C., Daw, N. D., Seymour, B., \& Dolan, R. J. (2008). Striatal activity underlies novelty-based choice in humans. Neuron, 58(6), 967-973. doi:http://dx.doi.org.idpproxy.reading.ac.uk/10.1016/j.neuron.2008.04.027

Wrzus, C., Hanel, M., Wagner, J., \& Neyer, F. J. (2013). Social Network Changes and Life Events Across the Life Span: A Meta-Analysis. Psychological Bulletin, 139(1), 53-80. 
Yan, Y., Jiang, W., Liu, L., Wang, X., Ding, C., Tian, Z., \& Zhou, R. (2014). Dopamine Controls Systemic Inflammation through Inhibition of NLRP3 Inflammasome. Cell, 160(1), 62-73. doi:10.1016/j.cell.2014.11.047

Yang, Z., \& Tang, A. C. (2011). Novelty-induced enhancement in spatial memory: Is infancy a critical period? Behavioural Brain Research, 219(1), 47-54. doi:https://doi.org/10.1016/j.bbr.2010.12.020

Yu, A. J., \& Dayan, P. (2005). Uncertainty, neuromodulation, and attention. Neuron, 46(4), 681-692. doi:http://dx.doi.org/10.1016/j.neuron.2005.04.026

Zecca, L., Stroppolo, A., Gatti, A., Tampellini, D., Toscani, M., Gallorini, M., . . Zucca, F. A. (2004). The role of iron and copper molecules in the neuronal vulnerability of locus coeruleus and substantia nigra during aging. Proceedings of the National Academy of Sciences of the United States of America, 101(26), 9843-9848.

Zecca, L., Youdim, M. B. H., Riederer, P., Connor, J. R., \& Crichton, R. R. (2004). Iron, brain ageing and neurodegenerative disorders. Nature Reviews. Neuroscience, 5(11), 863-873. doi:http://dx.doi.org/10.1038/nrn1537

Zhou, L.-w., Weiss, B., Freilich, J. S., \& Greenberg, L. H. (1984). Impaired recovery of alpha1-and alpha2-adrenergic receptors in brain tissue of aged rats. Journal of Gerontology, 39(5), 538-546. doi:10.1093/geronj/39.5.538

Ziegler, M., Cengia, A., Mussel, P., \& Gerstorf, D. (2015). Openness as a buffer against cognitive decline: The openness-fluid-crystallized-intelligence (OFCI) model applied to late adulthood. Psychology and Aging, 30(3), 573-588.

Zuckerman, M., Buchsbaum, M. S., \& Murphy, D. L. (1980). Sensation seeking and its biological correlates. Psychological Bulletin, 88(1), 187-214. 
Zuckerman, M., Eysenck, S. B., \& Eysenck, H. J. (1978). Sensation seeking in England and America: Cross-cultural, age, and sex comparisons. Journal of Consulting and Clinical Psychology, 46(1), 139-149. 


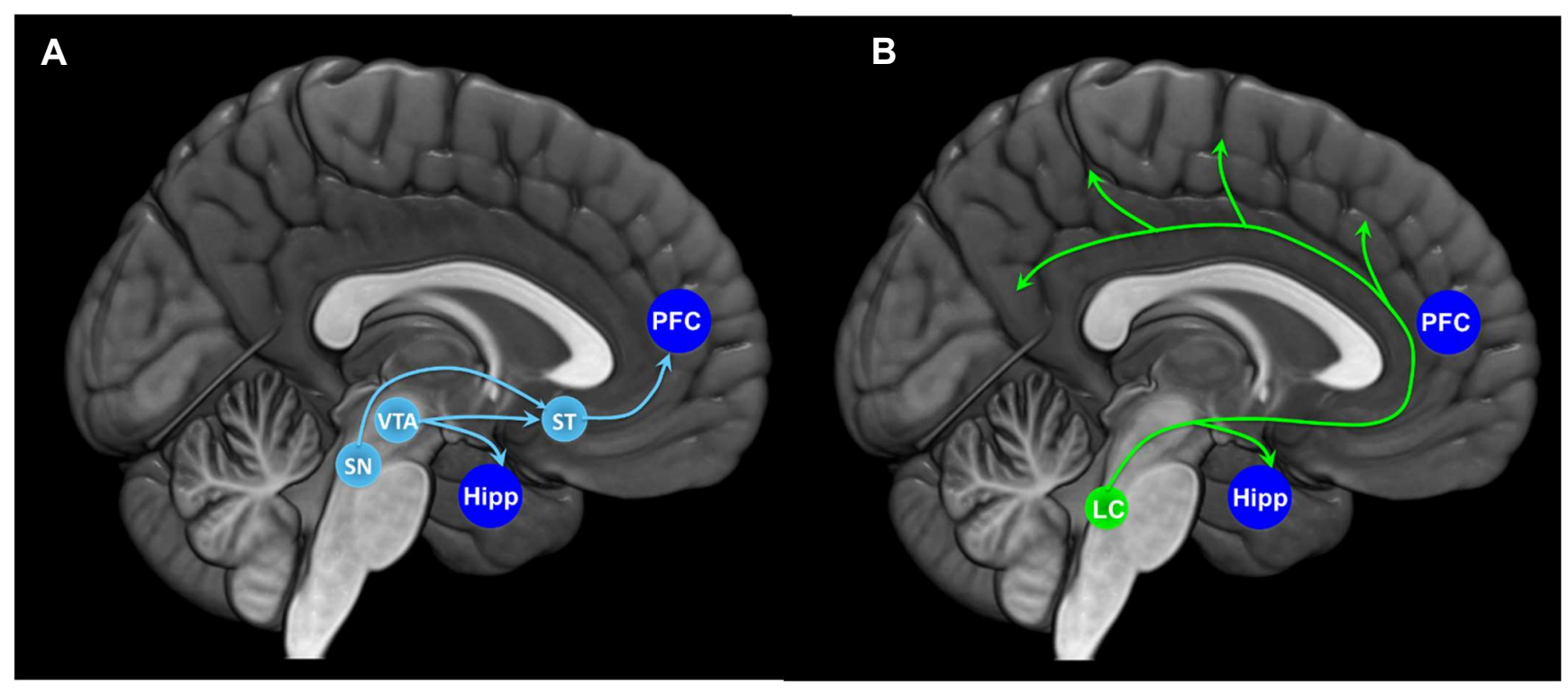

Figure 1. Brain regions important for curiosity. (A) The dopaminergic and $(B)$ the noradrenergic systems play critical roles in curiosity. (SN: Substantia Nigra, VTA: Ventral Tegmental Area, ST: Striatum, Hipp: Hippocampus, LC: Locus Coeruleus, PFC: Prefrontal Cortex.) 


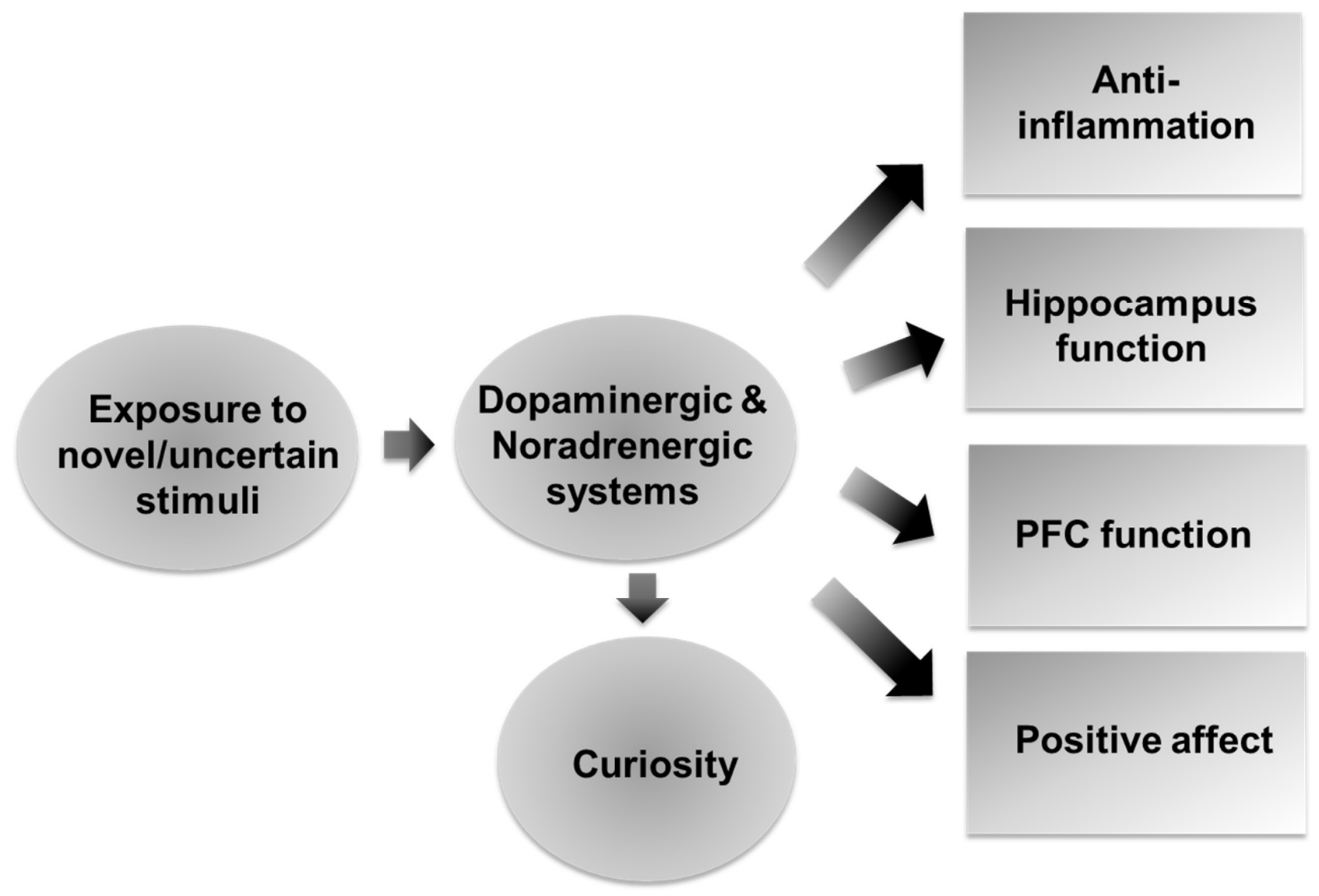

Figure 2. Effects of momentary feelings of curiosity when exposed to something novel and/or uncertain. 


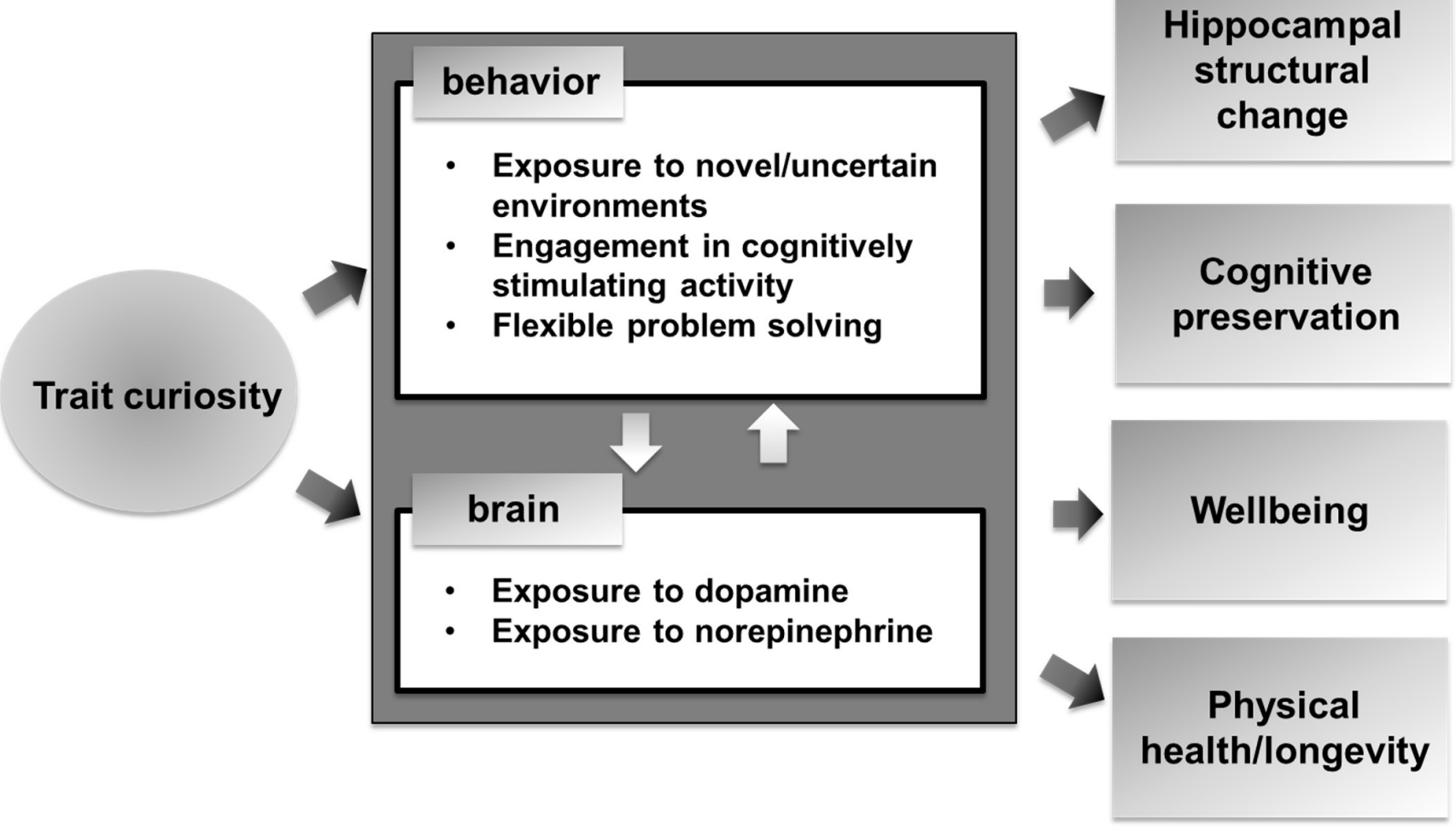

Figure 3. Effects of chronic tendency to experience curiosity on cognition, wellbeing, and physical functioning. 


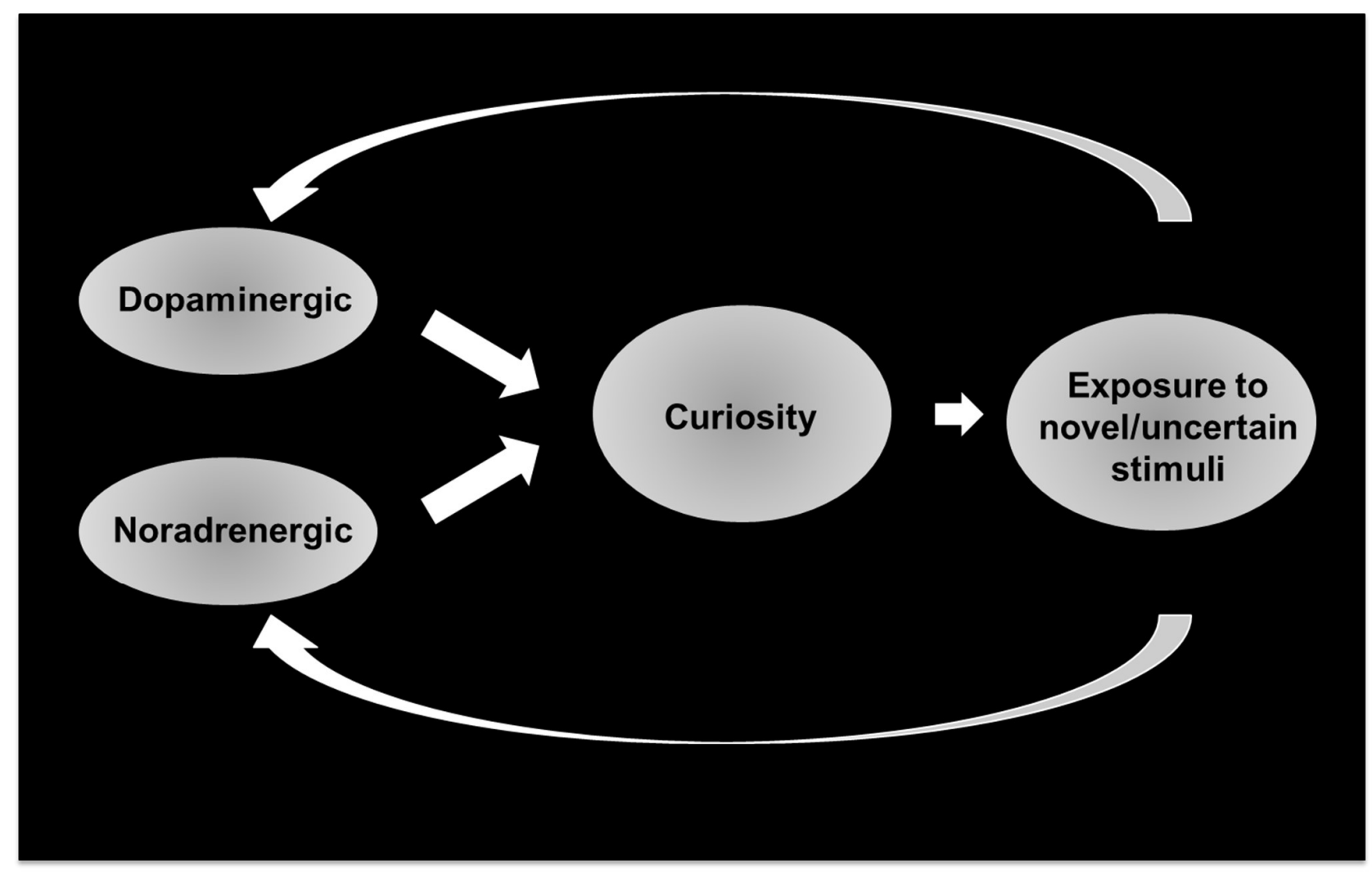

Figure 4. Positive feedback loop based on curiosity in aging. 